\title{
Parameters of Sustainable Development: Case of Arctic Liquefied Natural Gas Projects
}

\author{
Alexey Cherepovitsyn * and Olga Evseeva \\ Economics, Organization and Management Department, Saint-Petersburg Mining University, Vasilievsky Island, \\ 21 line 2, 199106 Saint-Petersburg, Russia; s185097@stud.spmi.ru \\ * Correspondence: Cherepovitsyn_AE@pers.spmi.ru; Tel.: +8-921-919-54-55
}

check for updates

Citation: Cherepovitsyn, A.; Evseeva, O. Parameters of Sustainable Development Case of Arctic Liquefied Natural Gas Projects. Resources 2021, 10, 1. https: / / dx.doi.org/10.3390/resources10010001

\section{Received: 20 October 2020}

Accepted: 17 December 2020

Published: 23 December 2020

Publisher's Note: MDPI stays neutral with regard to jurisdictional claims in published maps and institutional affiliations.

Copyright: (C) 2020 by the authors. Licensee MDPI, Basel, Switzerland. This article is an open access article distributed under the terms and conditions of the Creative Commons Attribution (CC BY) license (https: / / creativecommons.org/ licenses/by/4.0/).

\begin{abstract}
Effective management of the social and economic development of the Arctic zone of the Russian Federation is today a significant scientific and practical task. It requires an integrated approach to meet the expectations of the state, business and society. The main drivers of growth for remote Arctic territories are large investment projects, which not only create production and sectorial results, but also stimulate the development of related sectors of the economy. Additionally, they contribute to the formation of modern infrastructure in the region and create conditions for the broad introduction of innovative technologies. The current problem with territorial development strategic planning is the assessment of the results that have been achieved. This includes approved lists of indicators that do not allow for a full assessment of the impact of the implemented projects. Assessment on the achievement of the region goals is also murky. This indicates a lack of consistency in regional development management. This article defines the importance of the indicators for an assessment of sustainable development management. The model of achieving external effects in project activities is described. The concept of sustainability of large-capacity complexes for the production of liquefied natural gas (LNG) is also formulated. Based on the needs of micro- and macro-environment projects, a list of indicators for assessing the sustainability of LNG projects has been proposed. On the basis of the proposed indicator list, a sustainability analysis of three Arctic LNG projects was carried out. Based on the example of LNG production, it was concluded that approaches to assessing the sustainable socio-economic development of the Arctic region and its industrial systems are interrelated, but there are differences between them.
\end{abstract}

Keywords: sustainability; sustainable development; socio-economic development of the northern territories; innovation; projects; Arctic; liquefied natural gas

\section{Introduction}

The implementation of Russian strategic goals in the field of geopolitics, the economic development of Northern territories and a surge in hydrocarbon and other mineral raw materials production today is closely related to the development of the Arctic. The Arctic region has enormous energy and mineral resources concentrated in large and unique deposits [1,2]. Experts estimate that 20-25\% of the world hydrocarbon resources are located in the Russian Arctic zone and today about $80 \%$ of gas and $60 \%$ of oil from the total production of the country are produced there $[3,4]$. The Arctic mining complex is represented by deposits of iron, apatite, phosphorus, titanium, tungsten, copper, nickel, antimony, mercury, cobalt, gold, silver, platinum, rare metals and rare-earth elements [5,6].

The resource potential of the Russian Arctic is a national priority. The implementation of Arctic commodity projects will allow for the launch of innovative processes aimed at testing unique technological solutions and developing organizational and project management tools $[7,8]$. Among the most important tasks of Arctic hydrocarbon projects is the socio-economic development of northern territories, extended reproduction, and effective use of mineral and raw materials resources. Furthermore, the technological development of 
industrial systems, ensuring the sustainability of natural ecosystems, and ensuring energy and national security of the country as a whole, are significant goals [9].

There are serious challenges and requirements for the implementation of oil and gas projects in the coordinated system, especially the area of region-industrial systemsecology $[10,11]$. Often, promising areas for oil and gas production are removed from points of consumption. In this case, the lack of transport and industrial infrastructure may delay making investment decisions on projects. In addition, such areas may be located in the territories of indigenous peoples. There is a small degree of geological exploration of existing deposits, which increases the risk for new projects. Difficult operational conditions require the introduction of advanced technological solutions [12]. It is also expedient to consider the environmental factor since the activities of oil and gas companies have a significant impact on the environment, including the fact that new projects should leave a low carbon footprint [13-15]. The existing institutional environment must also be optimized and must contribute to the intensification of investment activities in the region. Legislative initiatives need to be supported by long-term strategic planning that reflects an effective set of measures for the development of businesses, social environments, integration aspects and environmental balance mechanisms [16].

The long-term goals of the state on the development of the Arctic are connected with the creation of large-scale transport and logistics, power, information and communication systems, safety and environmental protection complexes. There is a need to develop social infrastructure facilities, stimulate R\&D and increase demand for domestic technologies and equipment. It is expected to increase the geological study of the subsurface and increase the production of Arctic raw materials [17]. The indicated effects are planned to be obtained through the implementation of large investment projects, including the use of public-private partnership mechanisms. In this regard, sustainable regional development requires project participants to not only accumulate productive and financial resources, but also to take a specific approach. This approach allows for the development of industrial and infrastructural mineral-raw-material systems in conditions of high instability in energy markets and the objective complexity of solving technological and socio-economic problems [18,19].

An important element of effective regional development management is indicative planning and monitoring aimed at quantitative measurement and control of target results. It is obvious that the relationship of new investment projects with regional goals, which has been repeatedly noted in strategic planning documents, requires an appropriate list of indicators. These indicators take into account not only the technological characteristics of industrial development, but also the impact on the regional economy, population, and the state of the environment. It is noted that the idea of sustainable development is acquiring particular relevance in the Arctic [20].

One of the main directions of the Russian Arctic fuel and energy complex development is the implementation of liquefied natural gas (LNG) projects. The importance of LNG production today is largely determined by the need to diversify Russian gas export markets [21]. The implementation of large-scale Arctic LNG projects creates substantial opportunities for using the mineral resource potential of the region with a course for comprehensive infrastructure development of remote Northern territories, inter-industry interaction, ecological, innovative and technological development [22].

The feasibility of the development of the LNG industry in the Arctic is determined by a number of factors. These factors include large gas reserves in the coastal zone, low average temperatures in the region, the relatively low cost of natural gas production, and a good geographical location relative to key markets. Combined, these variables determine the high competitiveness of Arctic LNG compared to the leading countries of the LNG market.

Currently, there is one large-capacity LNG plant operating in the Arctic region-Yamal LNG. Two more LNG projects are planned for implementation: Arctic LNG-2 and Ob LNG. Their main characteristics are shown in Table 1. 
Table 1. Characteristics of Arctic LNG projects. Based on open data of operating companies. Budget efficiency is determined on the basis of discounting tax revenues to the regional budget for the period of project implementation.

\begin{tabular}{|c|c|c|c|}
\hline & Yamal LNG & Arctic LNG-2 & Ob LNG \\
\hline Capacity, million tons & 17.5 & 19.8 & 4.8 \\
\hline Starting year of the 1st lines & 2017 & 2023 & 2022 \\
\hline Number of production lines & 4 & 3 & 3 \\
\hline Resource base & The South-Tambeyskoye field & Utrenneye field & $\begin{array}{l}\text { Verkhnetiuteyskoye and } \\
\text { Zapadno-Seyakhinskoye } \\
\text { fields }\end{array}$ \\
\hline CAPEX, $\$$ billion & 27.5 & 21.3 & 5.7 \\
\hline Project participant & $\begin{array}{l}\text { Novatek, Total, China National } \\
\text { Petroleum Corporation (CNPC), } \\
\text { Silk Road Fund (SRF) }\end{array}$ & $\begin{array}{c}\text { Novatek, Total, CNPC, China } \\
\text { National Offshore Oil } \\
\text { Corporation (CNOOC), Japan } \\
\text { Arctic LNG }\end{array}$ & Novatek \\
\hline $\begin{array}{c}\text { Regional infrastructure } \\
\text { objects that are driven by } \\
\text { the project }\end{array}$ & $\begin{array}{c}\text { Sabetta seaport, Sabetta airport, } \\
\text { shift settlement, mobile phone } \\
\text { tower network }\end{array}$ & Utrenniy terminal & No data \\
\hline Job creation & 32,000 & No data & No data \\
\hline $\begin{array}{l}\text { Budget efficiency at the } \\
\text { regional level, \$ million }\end{array}$ & 1228 & 1664 & 409 \\
\hline
\end{tabular}

The experience of the Yamal LNG project has shown that its results not only show the beginning of development of the South Tambey gas condensate field and an increase in the share of Russian LNG in the global market, but also the creation of a major transport hub in the town of Sabetta, including a seaport and international airport, a shift settlement, a fleet of gas tankers and icebreakers and the development of the first Russian liquefaction technology. Also, the contribution to the development of the Northern Sea Route is paramount [23]. The construction of communication lines has provided access to highspeed data transmission in several cities of the Far North, and the project has created a significant number of jobs. The functioning asset is a stable source of revenue to the federal and regional budgets. According to experts of the SKOLKOVO Energy Center, the development of the LNG industry in the Arctic has already had a great synergistic effect in the preparation of some projects in the field of coal, gold, non-ferrous and rare metal ore production, which indicates the impact of increasing the investment attractiveness of the region especially for foreign investors [24].

Therefore, it can be concluded that the implementation of LNG projects has an impact on both the development of the region and the development of related industries through the formation of demand for related products and services, which indicates the presence of pronounced external effects. Given the previously noted relationship between the results of large-scale industrial projects and the development goals of the Arctic region, such effects need to be quantified and systematized, creating the possibility of managing their achievement.

The purpose of this study is to develop and test a list of sustainability indicators for large-scale LNG production complexes in accordance with the needs of the region and business interests. To achieve this goal, it is necessary to answer the following research questions:

(1) What is the value of a quantitative assessment of the results in sustainable development management and why is it needed for Arctic industrial systems?

(2) What is the concept of sustainability for LNG projects?

(3) What is the potential of Arctic LNG projects to generate positive economic, social, and environmental outcomes? 
(4) What should the sustainability indicators in a project approach be, and how will it differ from a corporate level assessment?

\section{Theoretical Background for Defining the Concept of Project Sustainability}

The term "sustainable development" became widely used after the "Our Common Future" report was presented by the Brundtland Commission [25]. The report provided a classic definition of sustainable development, which refers to "a process of change in which the exploitation of resources, the direction of investments, the orientation of technological development, and institutional change are all in harmony and enhance both current and future potential to meet human needs and aspirations" [26].

Russia approved the "Concept of the Russian Federation's Transition to Sustainable Development", presenting its own vision of the idea of sustainable development. According to the document, sustainable development means "stable socio-economic development that does not destroy its natural basis". The purpose of the gradual transition was determined "to ensure in the long term, a balanced solution to the problems of socio-economic development and preservation of a favorable environment and natural resource potential, meeting the needs of present and future generations of people".

Sustainable development is seen as a paradigm for thinking about the future, in which environmental, social and economic aspects are balanced in an effort to improve the quality of human life [27]. At the same time, the development itself testifies to a certain dynamic process. The term "sustainability" is used to describe the state of the system and its general target vision [28].

The most common description of sustainability involves three interconnected pillars, encompassing economic, social and environmental factors [29]. The sustainability model in scholarly writing is often depicted through three intersecting circles: society, environment and economy, with sustainability at the intersection of these spheres [30]. A similar relationship underlies the idea of the Triple Bottom Line (TBL) proposed by John Elkington and is often identified with the acronym "3P" (People, Planet, Profit) [31,32].

The characteristics of the interpretation and approach to sustainability assessment depend on the level of economic activity within which the evaluation object is considered. The Schukina L.V. study suggested that the following levels of sustainable development should be identified [33]:

- International (global)

- National

- Regional

- Sectorial

- Corporate

Despite the close relationship between the levels, each level has its own target trajectory of development. Sustainable development at the global level is focused on international partnerships to fight poverty and hunger, protect health and human rights, address climate change, preserve the biodiversity of the planet and its natural resources, prevent hostilities and protect the world's oceans [34].

At the national level, using the example of the Russian Federation, sustainable development involves ensuring national and environmental security, geopolitical interests, balanced development of economic sectors, resource availability, promotion of the wellbeing of the nation and realization of citizens' rights.

The components of sustainable development at the regional level include the stable functioning of industrial complexes, socio-economic and ecological systems of individual entities, comprehensive improvement of territories and settlements, provision of housing and communal services. These components create an impact on the population, industry, social, energy and transport infrastructure, improvement of well-being and the quality of local people's life, which ensures the preservation of culture and traditions [35].

Sustainable development of industry is determined by its competitiveness in domestic and foreign markets, innovation and technological potential, balanced functioning of 
production and economic units and their safety for the environment, efficiency of activity and the ability to provide necessary intra-industry proportions and connections $[15,36]$.

Sustainable development at the level of economic entities (corporate level) includes the creation of effective economic results while respecting the safety of production cycles, ensuring a high level of quality of produced products, minimization of a negative impact on the environment, development, social support and protection of workers' rights, implementation of CSR programs and implementation of advanced resource management practices [37-39].

Consequently, sustainable development goals and targets are largely defined by key challenges, opportunities, and constraints at each specific level. Sustainable development is closely linked to stakeholder theory, which is based on the principle of the harmonization of interests and expectations of direct and indirect participants in relation to ongoing processes $[40,41]$. Sustainable development of global and local systems is the result of interaction of the state, business and society in economic, social and environmental spheres [42]. Table 2 shows the main expectations of each group of stakeholders in relation to the three areas of sustainability.

Table 2. Challenges in social, ecology and economic spheres in the system of regional authorities -business-society.

\begin{tabular}{cccc}
\hline Social sphere & $\begin{array}{c}\text { State (Region) } \\
\text { Ensuring humanitarian security } \\
\text { and social stability in the region. }\end{array}$ & Human capital development. & Society \\
\hline Ecology & $\begin{array}{c}\text { Preservation of a favorable } \\
\text { environment, biodiversity, } \\
\text { reproduction of natural resources. }\end{array}$ & $\begin{array}{c}\text { Rational use of resources, } \\
\text { minimization of anthropogenic } \\
\text { impact on the environment. }\end{array}$ & $\begin{array}{c}\text { Safe state of the environment and } \\
\text { ubiquitous access to natural } \\
\text { resources according to basic needs. }\end{array}$ \\
\hline Economy & $\begin{array}{c}\text { Achieving maximum welfare of } \\
\text { the region's population, stable } \\
\text { growth of the territory's economy, } \\
\text { integration and penetration into } \\
\text { other local and global markets. }\end{array}$ & $\begin{array}{c}\text { Stable maintenance of } \\
\text { competitiveness, growth of } \\
\text { profit and capitalization. }\end{array}$ & $\begin{array}{c}\text { Adequate standard of living } \\
\text { (compared to the regional average } \\
\text { value and above) and minimization } \\
\text { of social differentiation. }\end{array}$ \\
\hline
\end{tabular}

An integral part of sustainable development is the sustainability assessment. According to Kates et al., the assessment of sustainability focused on providing decision makers the results of the analysis of global and local systems "nature-society" in the short and long term to help them determine what actions should or should not be taken in trying to make society more sustainable [43]. At the corporate level, sustainability indicators are also used in decision-making in addition to non-financial reporting. C. Searcy clarifies this application of assessment separately in board-level decision-making, corporate governance and supply chain management [44]. The latter is especially relevant for the LNG industry with a long value chain (gas production, gas liquefaction, LNG transportation, LNG regasification), since the high total value of a product requires sufficient attention at every stage of its creation [45].

According to $\mathrm{Wu} \& \mathrm{Wu}$, quantitative indicators clarify the meaning of sustainable development and allow for increasing the understanding of the complex interrelationships between the components of sustainability in practical terms, and thereby contribute to the development of science and practice of sustainable development [46]. When developing a list of sustainability indicators, it is necessary to specify which aspects of sustainability in the existing concept should be measured, which of the previously aspects not yet considered should be added and how these properties should be related to each other.

Indicators arise from the content of value illustrated by the phrase "we measure what we are concerned about" and at the same time form that value, which is concurrently illustrated by the phrase "we are concerned about what we are measuring" [47]. Each developed indicator allows for the qualitative or quantitative evaluation of a specific characteristic of a system striving for sustainability. Grouped into independent lists, they 
reflect the totality of stakeholders' interests and make it possible to assess progress in realizing their expectations.

"Sustainability indicators do not guarantee results, but results are impossible without the use of indicators" [47]. This statement reveals the third important function of sustainability indicators which are indicative planning and monitoring (Figure 1).

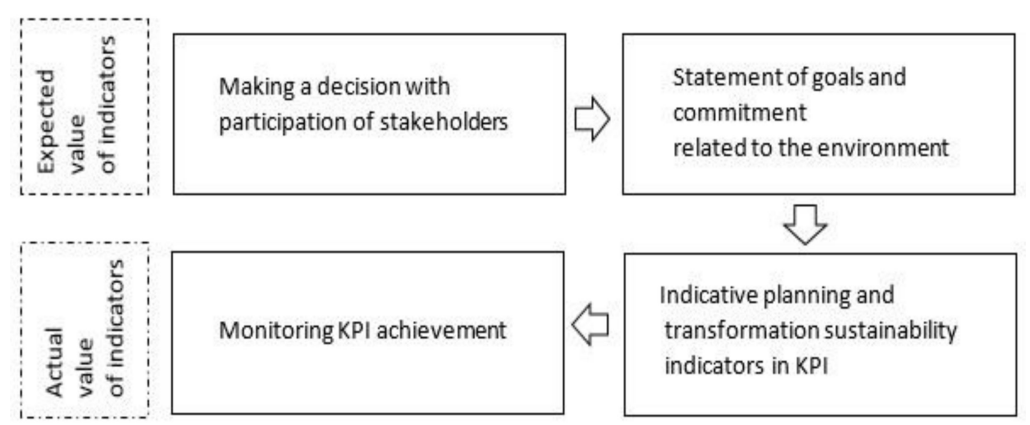

Figure 1. The importance of sustainability indicators in managing stakeholder expectations.

As shown in the diagram above, the stated measured results of sustainable development that meet the interests of stakeholders become a commitment to implement them for the environment. And the owner of the process (in the case of a project, the operator of the project) must integrate the work of creating these results into the content of the initiative. Sustainability indicators are already becoming key performance indicators (KPIs), reflecting the degree of commitment to compliance and as a tool for monitoring. Thus, the implementation of the KPI stage in the Stage-gate project management approach (the most common, since this approach allows to make investment decisions consistently, reducing risks) is a prerequisite for the transition between stages. For this, the KPI must be synchronized in accordance with the capabilities of the stage; the same KPI can be encountered at each stage of the project if the work, the quality of which it characterizes, is performed throughout the project. Regular monitoring of the KPI achievement status is carried out in the monitoring process, which is a key tool in ensuring the compliance of planned indicators with actual ones. Deviations identified during monitoring require an analysis of the causes of their occurrence, after which a cycle of corrective actions is launched.

The number of sustainability assessment tools developed and used today globally and locally is determined by hundreds of indicator and index lists [48]. Some of them are aimed at assessing specific areas of sustainable development, some suggest an integrated assessment. Sustainability assessment systems are based on the concept of sustainability, which does not have a single generally accepted interpretation. For this reason, the estimated parameters in the methodologies are different, and often such texts first explain what the concept is based on, and then disclose the content of the assessment [49].

The most famous and frequently mentioned lists of indicators of sustainability are lists proposed by international organizations. Among them are the United Nations Educational, Scientific and Cultural Organization (UNESCO), International Institute for Sustainable Development (IISD), Organization for Economic Co-operation and Development (OECD), United Nations Commission on Sustainable Development (CSD), Institute for European Environmental Policy, World Bank, European Environmental Agency, which are aimed primarily at assessing sustainable development at the global and national levels. Organizations such as S\&P Global, Global 100, Global Reporting Initiative (GRI), and the Russian Union of Industrialists and Entrepreneurs (RSPP) are involved in the assessment of sustainable development at the micro level. At the moment, there is no single, generally accepted approach to assessing the sustainability.

\section{Materials and Methods}

To address the research questions, open materials of analytical centers and specialized international organizations, the works of Russian and foreign scientists in the field of 
project management theory, sustainable development, strategic management, as well as regulatory and methodological documentation on research issues were used. A complex approach to the development of a list of sustainability indicators was provided by the use of methods of synthesis, analogy, grouping, comparison, as well as tools for strategic analysis, investment assessment and socio-economic forecasting, using the method of forward and backward linkages. The content of the indicator list is based on the key principles of sustainability assessment noted in the works of a researchers mentioned above.

The Arctic zone of the Russian Federation, which includes the territories of nine constituent entities of the Russian Federation, has been allocated to a separate object of state administration [50,51]. According to the state program titled "Socio-economic development of the Arctic zone of the Russian Federation", it is planned to provide a comprehensive solution of strategic tasks through the implementation of three SubPrograms. These include the "formation of support development zones and ensuring their functioning, creation of conditions for accelerated social and economic development of the Arctic zone of the Russian Federation", "development of the Northern Sea Route and provision of navigation in the Arctic", and the "creation of equipment and technologies of oil and gas and industrial engineering necessary for the development of mineral and raw materials resources of the Arctic zone of the Russian Federation". The names of subprograms reveal the priority areas of development in the region, and the indicators presented in the document clarify the content of the target results.

It is assumed that the dynamics of a number of indicators may be influenced by industrial complexes operating in the region. Thus, the intensification of production activities largely determines the improvement of macroeconomic indicators, as well as the growth of cargo turnover of the Northern Sea Route. Construction and modernization of industrial systems contributes to the growth of indicators characterizing innovative activity. As a result, it is possible to assess the contribution of industrial complexes to the socio-economic development of the region.

At the same time, each indicator list is aimed at a comprehensive assessment of the object to which it relates. In view of this, the unification of indicators is incorrect and an industrial project, even if it is focused on achieving regional goals, cannot be fully evaluated by the list of regional development indicators. This makes it necessary to develop separate list of indicators, taking into account the capabilities of projects and the interests of their stakeholders.

It should be noted that the assessment of indicators can be done in different ways (Table 3) [52-55].

Based on the analysis, it can be concluded that the assessment tool depends on the purpose of the analysis. The purpose of the analysis, in turn, can influence the list of indicators used, i.e., different indicator systems can be used for different analysis purposes. Their consistency in this case is determined by order, integrity in terms of analyzed characteristics coverage, connection with the final goal of the assessment and the presence of general principles in terms of the approach to the assessment.

In this study, the use of an assessment approach based on the calculation of an integral indicator is proposed in order to compare Arctic projects with each other. This approach is applicable in portfolio analysis and can be used for ranking projects. It allows for the formation of a conclusion about the priority of the project such as when making a decision to launch in conditions of limited resources. The construction of an integral indicator includes such stages as normalization, aggregation and weighting. These are aimed to bring indicators to a dimensionless form, to generalize indicators within individual groups and to differentiate the importance of each indicator in the overall set [56]. The project sustainability assessment algorithm used in this research is shown in the Figure 2. 
Table 3. Sustainability indicators assessment tools.

\begin{tabular}{|c|c|c|c|}
\hline Tool & Description & Benefits & Disadvantages \\
\hline $\begin{array}{l}\text { Qualitative indicators } \\
\text { assessment }\end{array}$ & $\begin{array}{l}\text { Description of the indicators } \\
\text { content without using quantitative } \\
\text { characteristics. }\end{array}$ & $\begin{array}{l}\text { Not all the indicators can be } \\
\text { evaluated; not every indicator } \\
\text { fully discloses its content in } \\
\text { numerical terms. }\end{array}$ & $\begin{array}{l}\text { Lack of objective indicators } \\
\text { comparability. }\end{array}$ \\
\hline Benchmarking & $\begin{array}{l}\text { Evaluation of indicators in } \\
\text { dimension relative to the best } \\
\text { analogues (values from the } \\
\text { maximum/minimum). }\end{array}$ & $\begin{array}{l}\text { Unified dimension of values } \\
\text { and their relativity, calculations } \\
\text { in terms of industry limits. }\end{array}$ & $\begin{array}{l}\text { Need for the best practices } \\
\text { continuous monitoring; } \\
\text { limited access to information } \\
\text { on each indicator. }\end{array}$ \\
\hline Scoring & $\begin{array}{l}\text { Experts put points on various } \\
\text { indicators within a regulated scale. }\end{array}$ & $\begin{array}{l}\text { Simplicity of the method and } \\
\text { uniform dimension of values. }\end{array}$ & $\begin{array}{l}\text { High subjectivity of } \\
\text { the assessment. }\end{array}$ \\
\hline $\begin{array}{l}\text { The integral } \\
\text { indicator calculation }\end{array}$ & $\begin{array}{l}\text { All the values are reduced to a } \\
\text { single indicator. In most cases, this } \\
\text { is done using a system of weights } \\
\text { and normalization of values. }\end{array}$ & $\begin{array}{l}\text { Allows to compare evaluation } \\
\text { objects with each other } \\
\text { comprehensively. }\end{array}$ & $\begin{array}{c}\text { The subjectivity when setting } \\
\text { the weights. }\end{array}$ \\
\hline $\begin{array}{l}\text { Indicators quantifica- } \\
\text { tion without integral } \\
\text { indicator calculation }\end{array}$ & $\begin{array}{c}\text { Evaluation of each indicator based } \\
\text { on quantitative values. }\end{array}$ & $\begin{array}{l}\text { The objectivity of the } \\
\text { calculations. }\end{array}$ & $\begin{array}{l}\text { Lack of consistency and } \\
\text { conclusion about the most } \\
\text { sustainable project or } \\
\text { an alternative. }\end{array}$ \\
\hline
\end{tabular}

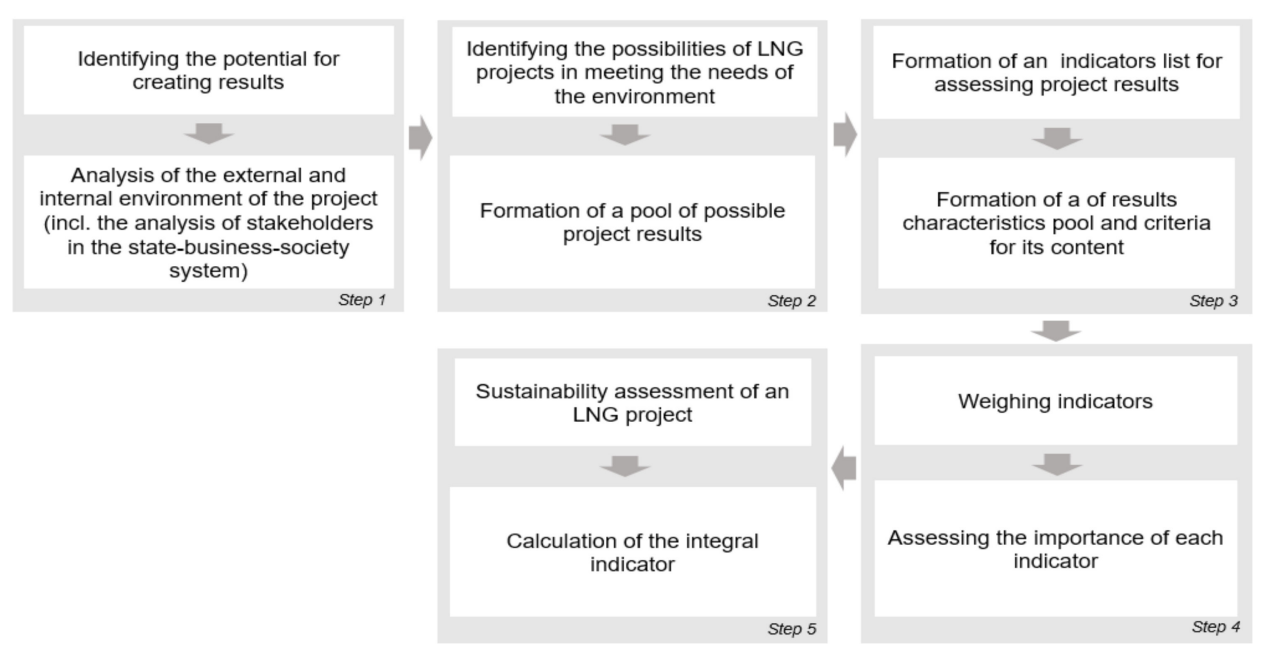

Figure 2. The project sustainability assessment algorithm.

The project sustainability assessment process involves an analytical stage, during which the potential for creating results is analyzed. Understanding current needs will allow to create maximum value for the environment, but it should be noted that the term "current needs" is dynamic, which means that the needs of the environment may change. This indicates a need for sustainable development management processes to function throughout the project, where sustainability indicators are reviewed and refined.

On this stage, special attention should be paid to approved strategies and programs that determine the current needs in the state-business-society system, as well as approved indicators for monitoring the implementation of these strategies and programs. Sources of information about needs in the external environment can be information from the media, as well as the use of various communication methods such as communication sessions, meetings, forums, conferences, etc.

On the next stage, it is necessary to analyze possibilities of LNG projects in solving urgent problems on regional, sectorial and national levels and compare them with the three- 
pillar conception of sustainability, structuring potential results in the fields of economy, social sphere and ecology.

The following stage involves forming a list of indicators. To do this, it is necessary to offer a quantitative characteristic for each potentially created result that corresponds to a certain interest (with units of measurement) and have previously formed requirements for its content. The requirements for the content of indicators determine the consistency of the list that they form. Furthermore, all the characteristics are grouped to reflect the completeness of the overall result assessment for each direction.

The next stage is weighting by spheres and groups. The individual areas of economy, ecology and social sphere may have an unequal number of indicators, and if not using weights, the assessment of each area may be distorted. Weighting within groups has the same goal. The philosophy of sustainable development is based on the principle of balance and equal coverage of the results in the aforementioned three areas. The same logic should be transposed to interest groups, which involves creating an alternative that provides maximum coverage in each interest group and will be more sustainable. In addition, even in strategic documents, goals may overlap. Indicators for these goals will give a higher value in total than for other goals. To avoid this, these indicators need to be aligned within groups. The weighting is based on the expert scores assigned for each indicator.

The final stage is to evaluate the project based on the developed list of indicators. Considering that each indicator has different scale and unit of measurement, it is necessary to use a normalization method aimed at reducing the indicators to a dimensionless form [56]. Since the purpose of the evaluation is to compare projects based on the principle of best matching their results to the needs of the environment, it is proposed to use the normalization method. In this case, each indicator correlates with a standard among alternatives. The benchmark in this case is the best value of the indicator among the projects under consideration. It should be noted that the benchmark can be both the largest and the lowest value of the indicator, for which it is necessary to have previously determined the orientation of each indicator.

\section{Results and Discussion}

Despite the fact that projects are initiated by companies, the assessment of their sustainability based on indicators of sustainable development at the corporate level is incorrect. The potential for creating results in the company's operational and project activities is different, because stakeholders and their interests in relation to the company and the project may differ. In addition, the project may involve external participants who create the uniqueness of the asset (Figure 3).

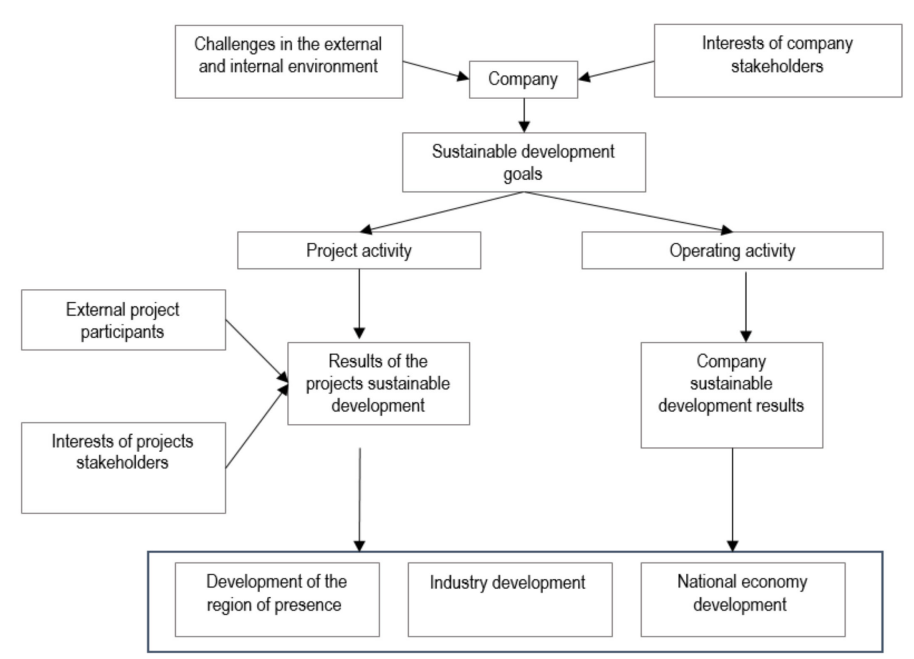

Figure 3. Conceptual model of the results arising in the company's project and operational activities. 
In addition to the different potential for creating results, the approach to evaluating project activities will also be different:

(1) The object of project evaluation is its unique result, material or non-material. When evaluating operating activities, the management system is mainly evaluated.

(2) The project is evaluated through effects on the level of influence on a certain object. When analyzing operating activities, usually volatile, constantly changing indicators are used, measured in dynamics.

(3) Project effects can be evaluated before the project is launched (with a certain probability of achievement).

(4) Project effects are focused on the long term and are calculated for the entire period of its implementation, which is strictly limited, with the possibility of clarification during the project lifecycle. Operating indicators are calculated primarily for reporting periods.

(5) Project effects are estimated, as a rule, according to the forecast principle, operating activities according to the actual one.

(6) Approaches to project impact assessment are less standardized than approaches to operational performance assessment. It is generally accepted that the investment performance of a project should be evaluated solely based on discounted cash flow modeling.

The external environment of project implementation is similar to the perimeter of the company that implements it. Accordingly, the external results of projects will affect the same areas as the company's activities, and will mainly affect the development of the region of presence, the industry and the national economy of the country as a whole, while simultaneously affecting the company's activities and satisfying the interests of project investors. The assessment of such an impact is made in the process of project sustainability analysis, aimed at a comprehensive assessment of the project results from the point of view of interests in the state-business-society system.

We propose to evaluate the sustainability of an LNG project as the project's ability to generate economic, social and environmental results that meet the expectations of stakeholders (Figure 4). With regard to LNG projects, such results should be aimed at the following targets:

(1) Minimizing the negative impact on the environment at the site of construction and operation of assets.

(2) The reproduction and efficient use of natural resources.

(3) The support of the local population and promoting the preservation of the cultural heritage of indigenous peoples.

(4) Implementation in the economic interests of project participants, ensuring a long-term contribution to the presence region economy.

(5) The development of its infrastructure framework.

(6) Innovative and technological development in the industry.

(7) Strengthening the position of Russian LNG in the world market.

Sustainable development of the project, i.e., the process of generating these results, must be not less than the period of its life cycle determined by the charter of the project, including the operational phase. The designated targets for sustainable development can be formulated in the form of the following goals:

1. Efficient subsurface using, energy efficiency and transition promotion to environmentally friendly energy sources. This involves a sound approach to resource exploitation that minimizes environmental damage, as well as creating conditions for large-scale LNG using, including regions with vulnerable ecosystems.

2. Creating economic value of the asset. This involves obtaining economic benefits for the main (owners of the LNG asset) and indirect (the state, suppliers and contractors, entities for which the implementation of this project has become a driver for devel- 
opment) project participants. It also includes the results that will become sources of additional growth in the future.

3. Participation in solving socially significant problems in the region of presence. This involves the implementation of CSR programs focused on the needs of local population.

expectations
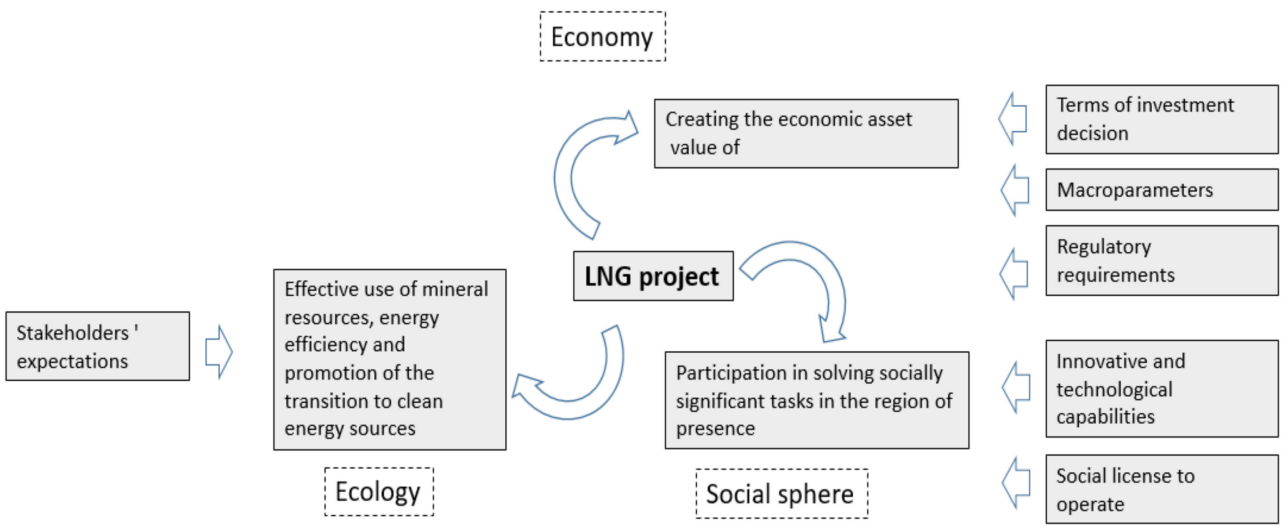

Figure 4. The concept of sustainability LNG project.

Sustainable development of the system is related to its ability to create economic, social and environmental results that meet the interests of stakeholders under existing restrictions. Based on the analysis of LNG projects implementing experience in Russia and in the world, we identified the main groups of stakeholders, their interests and potential contribution to the implementation of projects (Appendix A, Table A1).

For large-scale LNG projects, the list of expectations of stakeholders is quite high, which determines the number of possible effects that reflect its investment attractiveness. Moreover, the consequences of the project's implementation in the external environment, which determine its significance for the region and the industry (Appendix A, Table A2). It is important to note that the geographical and climatic features of the Arctic region in conditions of high dependence on foreign technologies and equipment require the activation of the innovative component at all stages of a project. This includes the organization and conduct of geological exploration, logistic support to industrial systems, organization and conduct of construction and installation work, the operation of production assets, and sales of finished products [57].

It is necessary to involve specialized universities and research institutes, scientific and technical centers and other participants offering advanced technological solutions for safe and efficient work in the extreme conditions of the North. For this reason, the effects of projects related to the development of innovations must also be taken into account.

Based on the analysis of the potential of Arctic LNG projects, the following groups of indicators can be identified for a comprehensive assessment of the results of such projectsmacroeconomic, international integration, investment, infrastructure, sectorial, inter-project cooperation, innovative, human development, development of regional culture, improving living standards, environmental pollution, transition to clean energy and energy efficiency (Appendix A, Table A3).

Indicators for assessing the sustainable development of industrial systems, in our opinion, should meet the following requirements:

1. Be universal in relation to other projects in the region of the same sector with an identical set of links in the production chain (for example, production-processing-sales).

2. Meet the interests of stakeholders of the project.

3. Be applicable for evaluation at any stage of the project, including pre-project development.

In accordance with the specified requirements, the following list of indicators for assessing the sustainability of Arctic LNG projects is proposed (Appendix A, Table A4). 
This list was tested in assessing the sustainability of the Yamal LNG project, as well as on the Arctic LNG-2 project planned for implementation with an investment decision already having been made. Lastly, it will be used on the Ob LNG project, on which an investment decision has not been made yet.

The indicators were evaluated using data from open sources, as well as the authors' own calculations. To set the weight coefficients, we used expert assessments obtained during a survey of a group of five experts in the field of project management and sustainable development of Russian oil and gas company. The principle of setting weights is described in the Methodology section. Bringing the indicators to a single view was also performed according to the principle described earlier-through the ratio of the indicator value to the best among the projects.

Calculations are given in Appendix A in Table A5 and based on data from open sources. The results of the calculations show that the Yamal LNG project is the most sustainable in terms of the characteristics of results that correspond to the interests of stakeholders (Figure 5). However, it is necessary to take into account the high estimation error associated with the limited amount of data on planned projects in open access, which is typical for the Ob LNG project. Even with limited data on the Arctic LNG-2 project, it can be concluded that there is sufficient potential to create results in the external environment comparable to the Yamal LNG project.

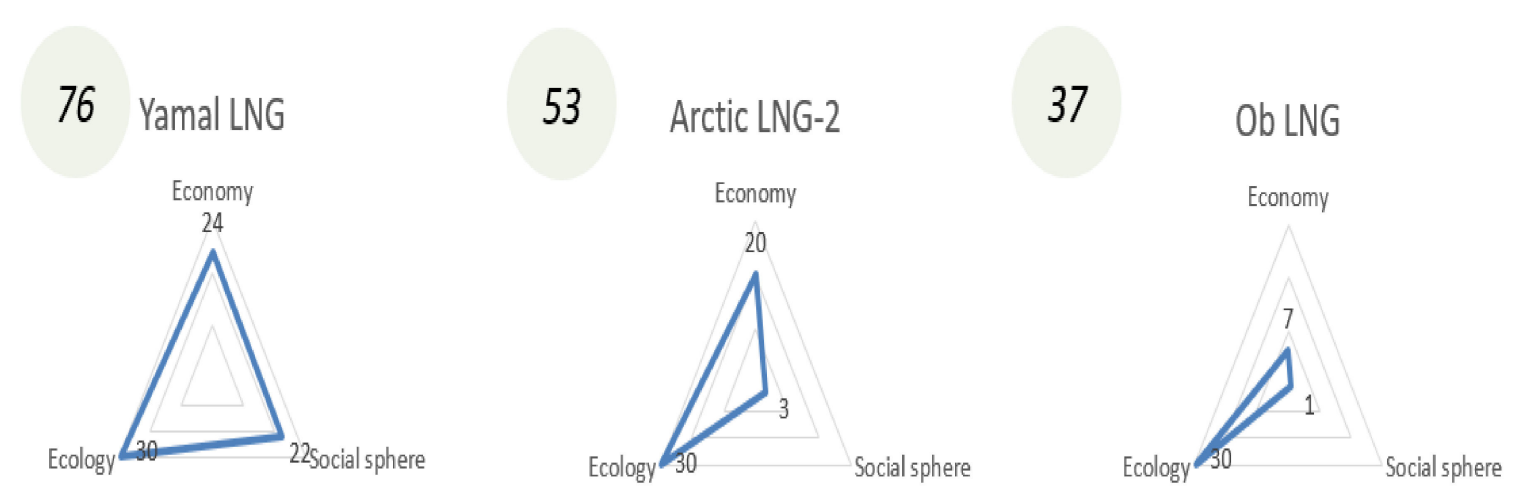

Figure 5. Integrated sustainability indicators for Arctic LNG projects and their distribution by sustainable development areas.

A rating system based on weights, the sum of which gives the final value " 100 ", and normalized according to the principle of bringing to the best result, assumes that the maximum value that can be obtained is 100 . This allows us to consider the integral stability indicator not only as an absolute value, but also as a relative one. However, it should be noted that sustainability indicators have different sensitivity to certain project parameters and not every indicator in the project can be increased/decreased to the reference one. For example, a number of indicators depend on the production capacity of a plant, which means that a less productive plant has a certain limit in generating economic, environmental and social results compared to a larger asset. This indicates that sustainability cannot have criteria and the conclusion about it is made in comparison with another object. A more sustainable option is one that provides the greatest coverage of the project results for the key interests of stakeholders in each area of sustainable development.

The proposed assessment approach is applicable in portfolio analysis, since it provides a summary of the status of each project in a specific area, which in this case, is in the field of sustainable development. However, it should be noted that with such an assessment system, the company should not seek to equalize the indicators since this can be achieved by reducing the benchmark indicators, but rather to search for additional potential improvements in lagging areas. Therefore, the sustainability portfolio should be monitored comprehensively for all projects with dynamic changes analysis in the values of each indicator. 
A promising area of application of the proposed indicators is mentioned early management of socio-economic development of the region. Large-scale LNG projects are systemforming in regional design and form the core for further development, inter-industry and inter-territorial interaction. The unique results of the projects created in the context of regional expectations and requirements should be evaluated on an early stage, included in comprehensive profile programs and regional development plans, and become specific objects of management, thereby creating maximum value for sustainable development of business, government and society in the long term.

\section{Conclusions}

Turning a strategy into real action requires quantifying the expected results, and thus allowing for evaluation of the effectiveness of the processes being launched. The existing system of strategic management of the socio-economic development of the Arctic region is in the process of formation. It has complex goals to ensure a functional approach to the creation of modern industrial complexes in remote Northern territories, linking production opportunities with the solution of social and environmental problems. There is an obvious need to synchronize government goals with the production programs of existing industrial systems as well as those that are planned or under development.

Large investment projects initiated on the basis of promising fields are system-forming, participate in solving the problems of integrated spatial development of the Arctic region, generate multiplicative effects for the industry to which they belong, as well as related industries, and stimulate the development of other promising local projects. The specifics of project management in relation to standard processes of production and economic activity determine a specific approach to evaluating the effectiveness of decisions made.

Indicators of sustainable socio-economic development of the region will differ from indicators of industrial systems development. This is due primarily to the fact that each project has its own industry affiliation. The corresponding composition of participants who determine the target vector of development and the profile of interaction with the external environment also contribute to this. Secondly, the indicators of regional development characterize, among other things, socio-demographic processes and the state of the ecosystem, which are determined by general regional trends and depend on the pace of development of the Arctic sectors of the economy as a whole. Subsequently, when conducting comprehensive monitoring of the solution of strategic tasks, an indicator assessment of both the socio-economic development of the region and industrial systems is necessary.

The proposed indicator list takes into account the needs of the Arctic region in the context of LNG projects capabilities. At the same time, the variable nature of the indicators should be noted, such as the list of indicators formed in response to the challenges in the state-business society system. These can be adjusted and clarified as the trends in the external and internal environment of the project change.

Author Contributions: Conceptualization, A.C.; Methodology O.E. and A.C., Formal Analysis O.E.; List of indicators O.E. and A.C., Writing-Original Draft Preparation O.E.; Supervision A.C. All authors have read and agreed to the published version of the manuscript.

Funding: The research was carried out with the financial support of a grant by the President of the Russian Federation for the state support of leading scientific schools of the Russian Federation, the number of the project NSh-2692.2020.5 "Modelling of ecological-balanced and economically sustainable development of hydrocarbon resources of the Arctic".

Data Availability Statement: The research is based on open available data. When calculating the projects integrated sustainability indicator (Appendix A, Table A5), data based on expert survey for indicator weighing were used. The calculated values of the projects integrated sustainability indicators (Appendix A, Table A5) and of projects budget efficiency at the regional level (Table 1) are original.

Conflicts of Interest: The authors declare no conflict of interest. 


\section{Appendix A}

Table A1. The main groups of LNG project's stakeholders, their interests and potential contribution to project implementation.

\begin{tabular}{|c|c|c|}
\hline Category of Stakeholders & Main Areas of Interests & Potential Contribution to Project Development \\
\hline Public authorities & $\begin{array}{l}\text { Diversification of gas export supplies, development of the raw material base, } \\
\text { innovative, technological and socio-economic development, improvement of the } \\
\text { country's image on the world stage, budget revenues from projects. }\end{array}$ & $\begin{array}{l}\text { State support for projects in the form of participation in financing } \\
\text { and providing tax incentives, opportunities for lobbying, LNG } \\
\text { projects integration in industry and regional strategies and } \\
\text { promoting their implementation in the context of socio-economic } \\
\text { development of regions and the country as a whole. }\end{array}$ \\
\hline Investors and credit organizations & $\begin{array}{l}\text { Return on investment, sustainable development and socially responsible investment, } \\
\text { creating and strengthening partnerships with companies participating in projects, } \\
\text { diversifying the project portfolio, and gaining experience in participating in } \\
\text { LNG projects. }\end{array}$ & $\begin{array}{l}\text { Provision of financial and other resources for } \\
\text { project implementation. }\end{array}$ \\
\hline $\begin{array}{l}\text { Industrial companies } \\
\text { (potential operators) }\end{array}$ & $\begin{array}{l}\text { Achievement of project goals, their implementation in accordance with deadlines } \\
\text { and budgets, technological development of companies, increasing the investment } \\
\text { attractiveness of business. }\end{array}$ & $\begin{array}{l}\text { Full responsibility for the projects implementation, promoting the } \\
\text { development of Russian LNG industry. }\end{array}$ \\
\hline Local communities & $\begin{array}{l}\text { Safety of used technologies, possibility of employment in the jobs created within the } \\
\text { projects, participation of the operator company in socio-economic development of } \\
\text { the region, preservation of traditional way of life. }\end{array}$ & $\begin{array}{l}\text { Human resources, an ability to purchase local goods and services, } \\
\text { "social license to operate". }\end{array}$ \\
\hline $\begin{array}{l}\text { Non-governmental environmental } \\
\text { organizations }\end{array}$ & $\begin{array}{l}\text { Safety and scientific feasibility of technologies, compliance with all environmental } \\
\text { standards and requirements in projects implementation, minimizing negative impact } \\
\text { on ecosystems. }\end{array}$ & $\begin{array}{l}\text { Opportunities for lobbying due to credibility of a number of } \\
\text { NGOs among the public. }\end{array}$ \\
\hline Media & $\begin{array}{l}\text { Transparency and accessibility of project information, open dialogue with operator } \\
\text { companies and project participants. }\end{array}$ & $\begin{array}{l}\text { A communication tool that contributes to positive reputation } \\
\text { formation of operating companies. }\end{array}$ \\
\hline $\begin{array}{l}\text { Control, supervision and } \\
\text { regulation bodies }\end{array}$ & $\begin{array}{l}\text { Reliability and regularity of project data provided, implementation of projects within } \\
\text { the framework of current legislation. }\end{array}$ & Favorable institutional conditions for conducting project work. \\
\hline Project teams & $\begin{array}{l}\text { Social responsibility of operator companies, high wages, decent working conditions, } \\
\text { opportunities for professional development. }\end{array}$ & $\begin{array}{c}\text { The main impact on the achievement of project goals and } \\
\text { performance indicators. }\end{array}$ \\
\hline Suppliers and Contractors & Long-term contracts and the stability of the interaction. & $\begin{array}{c}\text { The main impact on project performance in terms of cost, timing, } \\
\text { and quality. }\end{array}$ \\
\hline Consumers & Stable access to energy that is sold at market prices and meets quality requirements. & Stable demand for LNG. \\
\hline
\end{tabular}


Table A2. Opportunities for LNG projects in the context of regional and industrial interests.

\section{Region and Industry Strategic Challenges}

Comprehensive socio-economic development of the Arctic zone of the Russian Federation

Development of science and technology

Ensuring environmental safety

\section{LNG Project Opportunities}

Construction and modernization of transport, logistics, energy and social infrastructure facilities, gasification of settlements, provision of employment, implementation of programs for interaction with indigenous peoples, intensification of navigation along the Northern Sea Route (NSR), development of Russian fleet, revenues to the regional budget, growth of capitalization of territories, increased investment attractiveness of the region.

Development and implementation of equipment and technologies adapted for use in Arctic conditions, production of innovative knowledge-based products, stimulating the results of intellectual activity, intensifying interaction with research institutes, universities and scientific centers.

Establishment of modern information and communication infrastructure

Construction of information and telecommunication infrastructure facilities enabling the provision of communication services to the population and economic entities.

Minimizing the negative anthropogenic impact on the environment by creating conditions for the use of LNG as a fuel source and using of safe and energy-efficient technologies in the construction and operation of a production asset.

International cooperation in the Arctic

Promoting the attraction of foreign capital, creating conditions for the development of mutually beneficial partnerships, improving the efficiency of foreign economic activity.

Developing the natural gas market and meeting domestic energy demand Increase of natural gas production, gasification of settlements of the region of presence.

Flexible response to global gas market dynamics

Development of LNG production and consumption, ensuring the country's

leadership position in the global LNG market

Diversification of supplies and expansion of Russian natural gas sales.

The launch of new process lines has a direct impact on the increase in LNG production and allows to increase Russia's share in the global LNG market.

Increase in production and consumption of GMT (including using LNG)

Part of domestically produced LNG using as a clean energy medium. 
Table A3. Indicator groups for LNG project sustainability assessment.

Indicator Group

Macroeconomic

International integration

Investment

Infrastructure

Sectorial

Inter-project cooperation

Innovative

Human development

Development of regional culture

Improving living standards

Environmental pollution

They reflect negative imp atmosphere. They correspond to the interest to reduce anthropogenic impact on the environment.

Transition to clean energy

Reflect the impact of the project on increasing the share of clean energy in transport and energy sectors. They are in line with the interests of reducing greenhouse gas emissions in the national economy.

Energy efficiency

\section{Indicator Group Description}

Reflect the project's contribution to macroeconomic indicators. They correspond to the interests of increasing the capitalization of territories, increasing investment activity, increasing trade volumes, developing the budget system and the national economy as a whole.

They reflect the project's contribution to increasing the investment attractiveness of Russian projects for foreign partners. They correspond to interests of developing international Arctic cooperation.

Reflect return and return on investment. They correspond to interests on investment efficiency of the project.

They reflect the number of new, as well as reconstructed and modernized regional infrastructure facilities. They correspond to the interests of developing the infrastructure framework of the region.

They reflect the efficiency of using assets, as well as the project's contribution to increasing the production potential of LNG, increasing production, and intensifying gas exports. It is consistent with the interests of developing the resource base and diversifying the export supply of Russian gas.

Reflect the impact on the development of related projects. They correspond to the interests of increasing the investment attractiveness of the region, the development of Arctic shipbuilding and the development of the national economy as a whole.

They reflect the impact of the project on the increase of domestic developments in specialized areas. They correspond to interests in the field of innovative development and import substitution.

They reflect the impact of the project on increasing the level of employment of the population, the competitiveness of the labor force, and the expansion of choice opportunities. They correspond to the interests of providing opportunities for professional development and increasing demand in the labor market.

They reflect the impact of the project on the preservation of the cultural heritage of the region, including the life of the indigenous peoples of the North. They correspond to the interests of preserving the traditional way of life of local population.

They reflect the impact of the project on extending the perimeter of access to social benefits. They correspond to the interests of reducing social differentiation of society.

resources used in production process. They are consistent with the interests of effective energy using. 
Table A4. LNG project sustainability indicators list.

\begin{tabular}{|c|c|c|c|c|}
\hline Indicator & $\begin{array}{l}\text { Unit of Mea- } \\
\text { surement }\end{array}$ & The Contents of the Indicator & Group of Indicators & $\begin{array}{l}\text { The Field of Sustainable } \\
\text { Development }\end{array}$ \\
\hline State revenue & $\$$ bln. & $\begin{array}{l}\text { An indicator of the project contribution to budget revenues. It meets the interests of } \\
\text { the budget system development. }\end{array}$ & Macroeconomic & Economy \\
\hline Value of investments & $\$$ bln. & $\begin{array}{l}\text { An indicator of the project contribution to the total investment in the fixed capital of } \\
\text { the region. It meets the interests to increase investment activity. }\end{array}$ & Macroeconomic & Economy \\
\hline $\begin{array}{l}\text { Volume of marketable } \\
\text { products }\end{array}$ & $\$$ bln. & $\begin{array}{c}\text { An indicator that reflects the project contribution to production growth. It meets the } \\
\text { interests of the national economy development. }\end{array}$ & Macroeconomic & Economy \\
\hline Export Volume & $\$$ bln. & $\begin{array}{l}\text { An indicator that reflects the project contribution to increasing exports of products. It } \\
\text { meets the interests of the national economy development. }\end{array}$ & Macroeconomic & Economy \\
\hline $\begin{array}{l}\text { Number of foreign } \\
\text { shareholders of the project }\end{array}$ & units & $\begin{array}{c}\text { Indicator characterizing the project contribution to attract foreign partners. It is in the } \\
\text { interests of developing Arctic international cooperation. }\end{array}$ & $\begin{array}{l}\text { International } \\
\text { integration }\end{array}$ & Economy \\
\hline $\begin{array}{l}\text { Volume of foreign } \\
\text { capital raised }\end{array}$ & $\$$ bln. & $\begin{array}{c}\text { An indicator characterizing the project contribution to attract foreign capital. It meets } \\
\text { interests of developing Arctic international cooperation. }\end{array}$ & $\begin{array}{l}\text { International } \\
\text { integration }\end{array}$ & Economy \\
\hline Road construction & $\mathrm{km}$. & $\begin{array}{l}\text { An indicator of the project contribution to regional road construction. It meets the } \\
\text { interests of developing the infrastructure framework of the region. }\end{array}$ & Infrastructure & Economy \\
\hline $\begin{array}{l}\text { Creation of regional transport } \\
\text { infrastructure }\end{array}$ & units & $\begin{array}{l}\text { Indicator of the transport infrastructure facilities number in the region. It meets the } \\
\text { interests of developing the infrastructure framework of the region. }\end{array}$ & Infrastructure & Economy \\
\hline $\begin{array}{l}\text { Creation of regional } \\
\text { information infrastructure }\end{array}$ & units & $\begin{array}{l}\text { Indicator of the information infrastructure facilities number in the region. It meets the } \\
\text { interests of developing the infrastructure framework of the region. }\end{array}$ & Infrastructure & Economy \\
\hline $\begin{array}{l}\text { Reconstruction and } \\
\text { modernization of existing } \\
\text { transport infrastructure }\end{array}$ & units & $\begin{array}{l}\text { An indicator of the project contribution to the regional infrastructure modernization. } \\
\text { It meets the interests of developing the infrastructure framework of the region. }\end{array}$ & Infrastructure & Economy \\
\hline $\begin{array}{l}\text { Reconstruction and } \\
\text { modernization of existing } \\
\text { energy infrastructure }\end{array}$ & units & $\begin{array}{l}\text { An indicator of the project contribution to the regional infrastructure modernization. } \\
\text { It meets the interests of developing the infrastructure framework of the region. }\end{array}$ & Infrastructure & Economy \\
\hline $\begin{array}{l}\text { Volume of transportation } \\
\text { by NSR }\end{array}$ & $\begin{array}{l}\text { one million } \\
\text { tons/year }\end{array}$ & $\begin{array}{l}\text { Indicator characterizing the increase in cargo flow along the routes of the Northern Sea } \\
\text { Route (average for the period of the project implementation). It meets the interests to } \\
\text { increase the NSR turnover. }\end{array}$ & Infrastructure & Economy \\
\hline
\end{tabular}


Table A4. Cont.

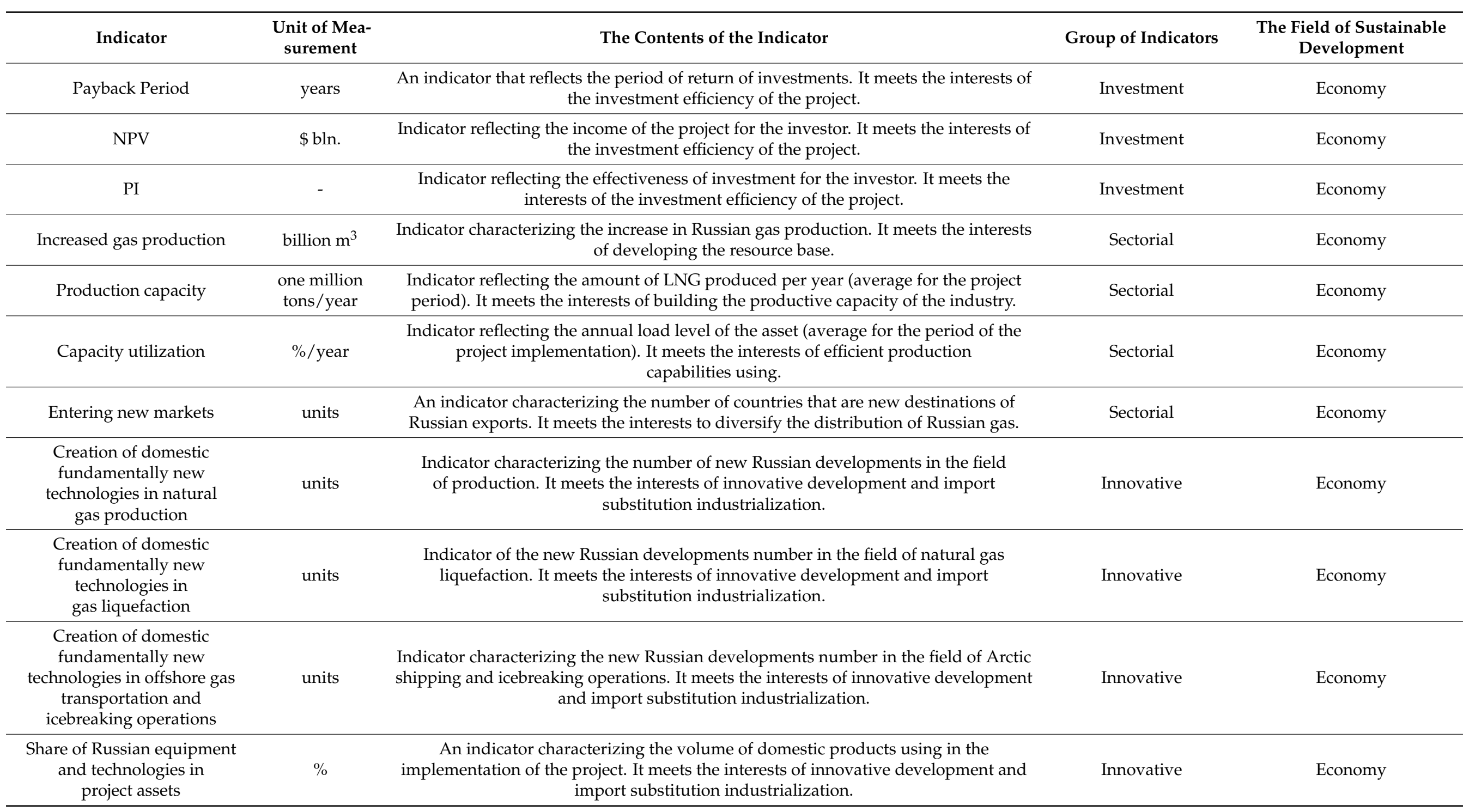


Table A4. Cont.

\begin{tabular}{|c|c|c|c|c|}
\hline Indicator & $\begin{array}{l}\text { Unit of Mea- } \\
\text { surement }\end{array}$ & The Contents of the Indicator & Group of Indicators & $\begin{array}{l}\text { The Field of Sustainable } \\
\text { Development }\end{array}$ \\
\hline $\begin{array}{l}\text { Use of project assets in } \\
\text { other projects }\end{array}$ & units & $\begin{array}{l}\text { An indicator that reflects the impact of the project on other projects. It meets the } \\
\text { interests to increase the investment attractiveness of the region. }\end{array}$ & $\begin{array}{l}\text { Inter-project } \\
\text { cooperation }\end{array}$ & Economy \\
\hline $\begin{array}{l}\text { Creation of specialized } \\
\text { complexes to meet the } \\
\text { production and technological } \\
\text { needs of the project }\end{array}$ & units & $\begin{array}{l}\text { An indicator characterizing the project contribution to stimulate the development of } \\
\text { new industries. It meets the interests of the national economy development. }\end{array}$ & $\begin{array}{l}\text { Inter-project } \\
\text { cooperation }\end{array}$ & Economy \\
\hline $\begin{array}{l}\text { Number of domestic vessels } \\
\text { built for the needs of the } \\
\text { project }\end{array}$ & units & $\begin{array}{l}\text { Indicator reflecting the impact of the project on the shipbuilding industry. It meets the } \\
\text { interests for the Arctic shipbuilding development. }\end{array}$ & $\begin{array}{l}\text { Inter-project } \\
\text { cooperation }\end{array}$ & Economy \\
\hline Job creation & $\begin{array}{l}\text { thousand } \\
\text { units }\end{array}$ & $\begin{array}{l}\text { An indicator characterizing the impact of the project on the new jobs creation. It meets } \\
\text { the interests of increasing the employment of the population and increasing labor } \\
\text { productivity in the economy. }\end{array}$ & Human development & Social sphere \\
\hline $\begin{array}{l}\text { Employment of the local } \\
\text { population in the project }\end{array}$ & $\%$ & $\begin{array}{l}\text { An indicator characterizing the participation of the local population in the project. It } \\
\text { meets the interests of increasing employment in the region. }\end{array}$ & Human development & Social sphere \\
\hline $\begin{array}{l}\text { Contribution to the } \\
\text { preservation of the traditional } \\
\text { way of life and the distinctive } \\
\text { culture of indigenous peoples }\end{array}$ & units & $\begin{array}{l}\text { Indicator of the number of programs for interaction with indigenous peoples. It is in } \\
\text { the interests of protecting the rights of the indigenous peoples of the North. }\end{array}$ & $\begin{array}{l}\text { Development of } \\
\text { regional culture }\end{array}$ & Social sphere \\
\hline Targeted training of workers & units & $\begin{array}{l}\text { Indicator characterizing the number of specialized educational programs developed } \\
\text { for the purpose of the project. It meets the interests of human development. }\end{array}$ & Human development & Economy \\
\hline $\begin{array}{l}\text { Building social infrastructure } \\
\text { in the region }\end{array}$ & units & $\begin{array}{l}\text { Indicator of the social infrastructure facilities number in the region. It meets the } \\
\text { interests of developing the infrastructure framework of the region. }\end{array}$ & $\begin{array}{l}\text { Improving living } \\
\text { standards }\end{array}$ & Social sphere \\
\hline $\begin{array}{l}\text { Reconstruction and } \\
\text { modernization of social } \\
\text { infrastructure in the region }\end{array}$ & units & $\begin{array}{l}\text { An indicator of the project contribution to the regional infrastructure modernization. It } \\
\text { meets the interests of developing the infrastructure framework of the region. }\end{array}$ & $\begin{array}{l}\text { Improving living } \\
\text { standards }\end{array}$ & Social sphere \\
\hline Gasification of Russian regions & units & $\begin{array}{l}\text { Indicator characterizing the number of gasified settlements. It meets the interests to } \\
\text { improve the quality of life. }\end{array}$ & $\begin{array}{l}\text { Improving living } \\
\text { standards }\end{array}$ & Social sphere \\
\hline Greenhouse gas emissions & $\begin{array}{l}\text { million } \\
\text { tons/year }\end{array}$ & $\begin{array}{l}\text { Indicator of greenhouse gas emissions (average for the project period). It meets the } \\
\text { interests to reduce the anthropogenic impact on the ecosystem. }\end{array}$ & $\begin{array}{l}\text { Environmental } \\
\text { pollution }\end{array}$ & Ecology \\
\hline
\end{tabular}


Table A4. Cont.

\begin{tabular}{|c|c|c|c|c|}
\hline Indicator & $\begin{array}{l}\text { Unit of Mea- } \\
\text { surement }\end{array}$ & The Contents of the Indicator & Group of Indicators & $\begin{array}{l}\text { The Field of Sustainable } \\
\text { Development }\end{array}$ \\
\hline Energy intensity of production & LNG KW/ton & $\begin{array}{l}\text { Indicator of production energy efficiency. It meets the interests of rational use } \\
\text { of resources. }\end{array}$ & Energy efficiency & Ecology \\
\hline Gas flaring & thousand $\mathrm{m}^{3}$ & $\begin{array}{l}\text { Indicator characterizing the amount of gas burned. It meets the interests to reduce the } \\
\text { anthropogenic impact on the ecosystem. }\end{array}$ & $\begin{array}{l}\text { Environmental } \\
\text { pollution }\end{array}$ & Ecology \\
\hline $\begin{array}{l}\text { LNG utilization volumes for } \\
\text { domestic vessel refueling }\end{array}$ & thousand $\mathrm{m}^{3}$ & $\begin{array}{l}\text { An indicator of the increase in the use of LNG in marine refueling. It meets the } \\
\text { interests to reduce the anthropogenic impact on the ecosystem. }\end{array}$ & $\begin{array}{l}\text { Transition to } \\
\text { clean energy }\end{array}$ & Ecology \\
\hline $\begin{array}{l}\text { LNG usage volumes for } \\
\text { power generation }\end{array}$ & thousand $\mathrm{m}^{3}$ & $\begin{array}{l}\text { An indicator of the increase in the use of LNG as a source for electricity generation. It } \\
\text { meets the interests to reduce the anthropogenic impact on the ecosystem. }\end{array}$ & $\begin{array}{l}\text { Transition to } \\
\text { clean energy }\end{array}$ & Ecology \\
\hline
\end{tabular}


Table A5. Calculation of integrated sustainability indicators for Arctic LNG projects

\begin{tabular}{|c|c|c|c|c|c|c|c|c|c|c|}
\hline \multirow[b]{2}{*}{ Indicator, Vector, Unit } & \multicolumn{3}{|c|}{ Indicator Value } & \multicolumn{3}{|c|}{ Normalized Value } & \multicolumn{3}{|c|}{ Weight Normalized Value } & \multirow[b]{2}{*}{ Justification } \\
\hline & $\begin{array}{l}\text { Yamal } \\
\text { LNG }\end{array}$ & $\begin{array}{c}\text { Arctic } \\
\text { LNG-2 }\end{array}$ & $\begin{array}{c}\text { Ob } \\
\text { LNG }\end{array}$ & $\begin{array}{l}\text { Yamal } \\
\text { LNG }\end{array}$ & $\begin{array}{c}\text { Arctic } \\
\text { LNG-2 }\end{array}$ & $\begin{array}{c}\text { Ob } \\
\text { LNG }\end{array}$ & $\begin{array}{l}\text { Yamal } \\
\text { LNG }\end{array}$ & $\begin{array}{c}\text { Arctic } \\
\text { LNG-2 }\end{array}$ & $\begin{array}{c}\mathrm{Ob} \\
\mathrm{LNG}\end{array}$ & \\
\hline $\begin{array}{l}\text { Volume of marketable } \\
\text { products, max, } \$ \text { bln. }\end{array}$ & 224.2 & 239.8 & 60.1 & 0.9 & 1.0 & 0.3 & 1.0 & 1.1 & 0.3 & $\begin{array}{l}\text { Authors' calculation based on LNG production volume } \\
\text { and price. }\end{array}$ \\
\hline State revenue, $\max , \$$ bln. & 5.7 & 5.1 & 1.3 & 1.0 & 0.9 & 0.2 & 1.2 & 1.1 & 0.3 & $\begin{array}{c}\text { Authors' calculation based on modeling and discounting of cash } \\
\text { flows in terms of budget efficiency. }\end{array}$ \\
\hline $\begin{array}{l}\text { Value of investments, max, } \\
\qquad \text { bln. }\end{array}$ & 28 & 21 & 6 & 1.0 & 0.8 & 0.2 & 1.3 & 1.0 & 0.3 & Open source project costs data. \\
\hline Export volume, max, \$ bln. & 224.2 & 239.8 & 60.1 & 0.9 & 1.0 & 0.3 & 1.1 & 1.2 & 0.3 & $\begin{array}{l}\text { Authors' calculation based on LNG production volume and } \\
\text { price (authors' assumption that the project volume of production } \\
\text { will correspond to the volume of exports). }\end{array}$ \\
\hline $\begin{array}{l}\text { Number of foreign } \\
\text { shareholders of the project, } \\
\text { max, units }\end{array}$ & 3 & 4 & 0 & 0.8 & 1.0 & 0.0 & 1.8 & 2.3 & 0.0 & $\begin{array}{c}\text { Data on project participants from open sources. Information is } \\
\text { shown in the Table } 1 \text { of this article. }\end{array}$ \\
\hline $\begin{array}{l}\text { Volume of foreign capital } \\
\text { raised, max, } \$ \text { bln. }\end{array}$ & 13 & 9 & 0 & 1.0 & 0.6 & 0.0 & 2.4 & 1.5 & 0.0 & $\begin{array}{c}\text { Data on the structure of participation in project capital from } \\
\text { open sources. }\end{array}$ \\
\hline Road construction, max, km. & 0 & 0 & 0 & 0 & 0 & 0 & 0 & 0 & 0 & $\begin{array}{l}\text { Data on road construction volumes from open sources (not } \\
\text { available currently). }\end{array}$ \\
\hline $\begin{array}{l}\text { Creation of regional energy } \\
\text { infrastructure, max, units }\end{array}$ & 1 & 0 & 0 & 1.0 & 0.0 & 0.0 & 0.7 & 0.0 & 0.0 & $\begin{array}{l}\text { Data on construction of regional energy infrastructure from open } \\
\text { sources. For the Yamal LNG project was created the Yamal LNG } \\
\text { TPP. There is no information about other projects. }\end{array}$ \\
\hline $\begin{array}{l}\text { Creation of regional transport } \\
\text { infrastructure, max, units }\end{array}$ & 2 & 1 & 0 & 1.0 & 0.5 & 0.0 & 0.7 & 0.3 & 0.0 & $\begin{array}{l}\text { Data on construction of regional transport infrastructure } \\
\text { facilities from open sources. For the Yamal LNG project were } \\
\text { created the seaport and the airport. For the Arctic LNG-2 project } \\
\text { is planned the marine terminal. There is no data for Ob LNG. }\end{array}$ \\
\hline $\begin{array}{l}\text { Creation of regional } \\
\text { information infrastructure, } \\
\max \text {, units }\end{array}$ & 1 & 0 & 0 & 1.0 & 0.0 & 0.0 & 0.6 & 0.0 & 0.0 & $\begin{array}{l}\text { Data on construction of regional information infrastructure } \\
\text { facilities from open sources. For the Yamal LNG was built a } \\
\text { network of mobile communication towers. There is no data for } \\
\text { other projects. }\end{array}$ \\
\hline
\end{tabular}


Table A5. Cont.

\begin{tabular}{|c|c|c|c|c|c|c|c|c|c|c|}
\hline \multirow[b]{2}{*}{ Indicator, Vector, Unit } & \multicolumn{3}{|c|}{ Indicator Value } & \multicolumn{3}{|c|}{ Normalized Value } & \multicolumn{3}{|c|}{ Weight Normalized Value } & \multirow[b]{2}{*}{ Justification } \\
\hline & $\begin{array}{l}\text { Yamal } \\
\text { LNG }\end{array}$ & $\begin{array}{l}\text { Arctic } \\
\text { LNG-2 }\end{array}$ & $\begin{array}{l}\text { Ob } \\
\text { LNG }\end{array}$ & $\begin{array}{l}\text { Yamal } \\
\text { LNG }\end{array}$ & $\begin{array}{l}\text { Arctic } \\
\text { LNG-2 }\end{array}$ & $\begin{array}{l}\text { Ob } \\
\text { LNG }\end{array}$ & $\begin{array}{l}\text { Yamal } \\
\text { LNG }\end{array}$ & $\begin{array}{l}\text { Arctic } \\
\text { LNG-2 }\end{array}$ & $\begin{array}{l}\text { Ob } \\
\text { LNG }\end{array}$ & \\
\hline $\begin{array}{c}\text { Reconstruction and } \\
\text { modernization of existing } \\
\text { transport infrastructure, } \\
\text { max, units }\end{array}$ & 0 & 0 & 0 & 0 & 0 & 0 & 0 & 0 & 0 & $\begin{array}{l}\text { Data on reconstruction and modernization of facilities from open } \\
\text { sources (not available currently). }\end{array}$ \\
\hline $\begin{array}{l}\text { Reconstruction and } \\
\text { modernization of existing } \\
\text { energy infrastructure }\end{array}$ & 0 & 0 & 0 & 0 & 0 & 0 & 0 & 0 & 0 & $\begin{array}{l}\text { Data on reconstruction and modernization of facilities from open } \\
\text { sources (not available currently). }\end{array}$ \\
\hline $\begin{array}{l}\text { Volume of transportation by } \\
\text { NSR, max, one million } \\
\text { tons/year }\end{array}$ & 17.5 & 19.8 & 4.8 & 0.9 & 1.0 & 0.2 & 0.6 & 0.7 & 0.2 & On the basis of data on production capacity. \\
\hline Payback Period, min, years & 20 & 16 & 10 & 0.5 & 0.6 & 1.0 & 0.8 & 1.0 & 1.6 & $\begin{array}{l}\text { Authors' calculation based on modeling and discounting the } \\
\text { cash flows in terms of commercial efficiency. }\end{array}$ \\
\hline NPV, max, \$ bln. & 4.9 & 5.2 & 1.2 & 0.9 & 1.0 & 0.2 & 1.5 & 1.6 & 0.4 & $\begin{array}{l}\text { Authors' calculation based on modeling and discounting the } \\
\text { cash flows in terms of commercial efficiency. For the Yamal LNG } \\
\text { project, tax benefits are included in the cash flows. For other } \\
\text { projects, there is no data on tax benefits yet. The calculations are } \\
\text { based on the project capacity of the plant, taking into account } \\
\text { current prices and authors' assumption of } 100 \% \text { export sales } \\
\text { (data on domestic use are not available) and } 40 \text {-year operational } \\
\text { phase period. We also assumed that domestic consumption can } \\
\text { be achieved by exceeding the project capacity due to low } \\
\text { temperatures. Excess of project plant capacity was not taken into } \\
\text { account in the cash flow calculations. }\end{array}$ \\
\hline PI, max & 1.26 & 1.57 & 1.54 & 0.8 & 1.0 & 1.0 & 1.3 & 1.6 & 1.6 & $\begin{array}{l}\text { Authors' calculation based on modeling and discounting the } \\
\text { cash flows in terms of commercial efficiency. }\end{array}$ \\
\hline $\begin{array}{l}\text { Increased gas production, max, } \\
\text { billion } \mathrm{m}^{3}\end{array}$ & 540 & 560 & 140 & 1.0 & 1.0 & 0.3 & 1.2 & 1.3 & 0.3 & $\begin{array}{c}\text { Authors' calculation based on the production demand in the raw } \\
\text { material base of the liquefaction plant. }\end{array}$ \\
\hline $\begin{array}{l}\text { Production capacity, max, one } \\
\text { million tons/year }\end{array}$ & 17.5 & 19.8 & 4.8 & 0.9 & 1.0 & 0.2 & 1.0 & 1.1 & 0.3 & $\begin{array}{l}\text { Open source data. Information is shown in the Table } 1 \text { of this } \\
\text { article. }\end{array}$ \\
\hline
\end{tabular}


Table A5. Cont.

\begin{tabular}{|c|c|c|c|c|c|c|c|c|c|c|}
\hline \multirow[b]{2}{*}{ Indicator, Vector, Unit } & \multicolumn{3}{|c|}{ Indicator Value } & \multicolumn{3}{|c|}{ Normalized Value } & \multicolumn{3}{|c|}{ Weight Normalized Value } & \multirow[b]{2}{*}{ Justification } \\
\hline & $\begin{array}{l}\text { Yamal } \\
\text { LNG }\end{array}$ & $\begin{array}{l}\text { Arctic } \\
\text { LNG-2 }\end{array}$ & $\begin{array}{c}\mathrm{Ob} \\
\text { LNG }\end{array}$ & $\begin{array}{l}\text { Yamal } \\
\text { LNG }\end{array}$ & $\begin{array}{l}\text { Arctic } \\
\text { LNG-2 }\end{array}$ & $\begin{array}{c}\mathrm{Ob} \\
\text { LNG }\end{array}$ & $\begin{array}{l}\text { Yamal } \\
\text { LNG }\end{array}$ & $\begin{array}{l}\text { Arctic } \\
\text { LNG-2 }\end{array}$ & $\begin{array}{c}\mathrm{Ob} \\
\text { LNG }\end{array}$ & \\
\hline $\begin{array}{l}\text { Capacity utilization, max, } \\
\% / \text { year }\end{array}$ & 111 & 111 & 111 & 1.0 & 1.0 & 1.0 & 1.1 & 1.1 & 1.1 & $\begin{array}{l}\text { Based on the authors' assumptions, taking into account current } \\
\text { experience with exceeding production volumes over production } \\
\text { capacity about } 11 \% \text {. There is no reason to believe that excess } \\
\text { production capacity will differ between others Arctic } \\
\text { LNG projects. }\end{array}$ \\
\hline $\begin{array}{l}\text { Entering new markets, } \\
\text { max, units }\end{array}$ & 6 & 0 & 0 & 1.0 & 0.0 & 0.0 & 1.2 & 0.0 & 0.0 & $\begin{array}{l}\text { Data from open sources. For the Yamal LNG project, these are } \\
\text { the USA, Canada, Malta, Spain, Brazil, Panama. There is no data } \\
\text { for the Ob LNG and Arctic LNG-2 projects. }\end{array}$ \\
\hline $\begin{array}{l}\text { Creation of domestic } \\
\text { fundamentally new } \\
\text { technologies in natural gas } \\
\text { production, max, units }\end{array}$ & 0 & 0 & 0 & 0 & 0 & 0 & 0 & 0 & 0 & $\begin{array}{l}\text { Data on the number of new technologies from open sources (not } \\
\text { available currently). }\end{array}$ \\
\hline $\begin{array}{l}\text { Creation of domestic } \\
\text { fundamentally new } \\
\text { technologies in gas } \\
\text { liquefaction, max, units }\end{array}$ & 1 & 0 & 0 & 1.0 & 0.0 & 0.0 & 1.4 & 0.0 & 0.0 & $\begin{array}{l}\text { Data on the number of new technologies from open sources. For } \\
\text { the Yamal LNG project, the first Russian gas liquefaction } \\
\text { technology «Arctic cascade» was created. There is no data for } \\
\text { other projects. }\end{array}$ \\
\hline $\begin{array}{l}\text { Creation of domestic } \\
\text { fundamentally new } \\
\text { technologies in offshore gas } \\
\text { transportation and icebreaking } \\
\text { operations, max, units }\end{array}$ & 0 & 0 & 0 & 0 & 0 & 0 & 0 & 0 & 0 & $\begin{array}{l}\text { Data on the number of technologies from open sources (not } \\
\text { available currently). }\end{array}$ \\
\hline $\begin{array}{l}\text { Share of Russian equipment } \\
\text { and technologies in project } \\
\text { assets, max, \% }\end{array}$ & 15 & 0 & 0 & 1.0 & 0.0 & 0.0 & 1.2 & 0.0 & 0.0 & $\begin{array}{l}\text { Open source data (not available currently for the Arctic LNG-2 } \\
\text { and the Ob LNG projects). }\end{array}$ \\
\hline
\end{tabular}


Table A5. Cont.

\begin{tabular}{|c|c|c|c|c|c|c|c|c|c|c|}
\hline \multirow[b]{2}{*}{ Indicator, Vector, Unit } & \multicolumn{3}{|c|}{ Indicator Value } & \multicolumn{3}{|c|}{ Normalized Value } & \multicolumn{3}{|c|}{ Weight Normalized Value } & \multirow[b]{2}{*}{ Justification } \\
\hline & $\begin{array}{l}\text { Yamal } \\
\text { LNG }\end{array}$ & $\begin{array}{l}\text { Arctic } \\
\text { LNG-2 }\end{array}$ & $\begin{array}{c}\mathrm{Ob} \\
\text { LNG }\end{array}$ & $\begin{array}{l}\text { Yamal } \\
\text { LNG }\end{array}$ & $\begin{array}{l}\text { Arctic } \\
\text { LNG-2 }\end{array}$ & $\begin{array}{c}\mathrm{Ob} \\
\mathrm{LNG}\end{array}$ & $\begin{array}{l}\text { Yamal } \\
\text { LNG }\end{array}$ & $\begin{array}{l}\text { Arctic } \\
\text { LNG-2 }\end{array}$ & $\begin{array}{c}\mathrm{Ob} \\
\mathrm{LNG}\end{array}$ & \\
\hline $\begin{array}{l}\text { Use of project assets in other } \\
\text { projects, max, units }\end{array}$ & 8 & 0 & 0 & 1.0 & 0.0 & 0.0 & 1.6 & 0.0 & 0.0 & $\begin{array}{l}\text { According to data from open sources, the Yamal LNG project } \\
\text { infrastructure will be used to implement the Arctic LNG-2, Ob } \\
\text { LNG, Arctic LNG-1, Arctic LNG-3 projects, and project of } \\
\text { production coal, gold, non-ferrous and rare metal ores (the } \\
\text { number and projects titles are not reported, the calculation takes } \\
\text { into account the value 4). There is no publicly available data for } \\
\text { other projects. }\end{array}$ \\
\hline $\begin{array}{l}\text { Creation of specialized } \\
\text { complexes to meet the } \\
\text { production and technological } \\
\text { needs of the project max, units }\end{array}$ & 0 & 1 & 0 & 0.0 & 1.0 & 0.0 & 0.0 & 1.4 & 0.0 & $\begin{array}{c}\text { For the Arctic LNG-2 project, it is a Center for the construction of } \\
\text { large-capacity offshore structures. There is no data for } \\
\text { other projects. }\end{array}$ \\
\hline $\begin{array}{l}\text { Number of domestic vessels } \\
\text { built for the needs of the } \\
\text { project max, units }\end{array}$ & 0 & 15 & 0 & 0.0 & 1.0 & 0.0 & 0.0 & 1.8 & 0.0 & Open source data. No data available for the Ob LNG project. \\
\hline $\begin{array}{l}\text { Job creation max, } \\
\text { thousand units }\end{array}$ & 32 & 24.7 & 6.7 & 1.0 & 0.8 & 0.2 & 3.9 & 3.0 & 0.8 & $\begin{array}{l}\text { Open source data for the Yamal LNG project and the authors' } \\
\text { assumption that for the other projects the approximate number } \\
\text { of jobs will depend on the amount of investment (specific value } \\
\text { of the jobs number per investment unit). }\end{array}$ \\
\hline $\begin{array}{l}\text { Employment of the local } \\
\text { population in the project } \\
\qquad \max \%\end{array}$ & 0 & 0 & 0 & 0 & 0 & 0 & 0 & 0 & 0 & Open source data (not available currently). \\
\hline $\begin{array}{l}\text { Targeted training for workers } \\
\text { max, units }\end{array}$ & 1 & 0 & 0 & 1.0 & 0.0 & 0.0 & 4.0 & 0.0 & 0.0 & $\begin{array}{l}\text { Open source data. For the Yamal LNG project, it is a specialized } \\
\text { training program based on the «Innopolis» center. For other } \\
\text { projects there is no information. }\end{array}$ \\
\hline $\begin{array}{l}\text { Contribution to the } \\
\text { preservation of the traditional } \\
\text { way of life and the distinctive } \\
\text { culture of indigenous peoples } \\
\text { max, units }\end{array}$ & 1 & 0 & 0 & 1.0 & 0.0 & 0.0 & 11.1 & 0.0 & 0.0 & $\begin{array}{l}\text { Open source data. For the Yamal LNG project transitions for } \\
\text { deer were built. For other projects there is no information. }\end{array}$ \\
\hline
\end{tabular}


Table A5. Cont.

\begin{tabular}{|c|c|c|c|c|c|c|c|c|c|c|}
\hline \multirow[b]{2}{*}{ Indicator, Vector, Unit } & \multicolumn{3}{|c|}{ Indicator Value } & \multicolumn{3}{|c|}{ Normalized Value } & \multicolumn{3}{|c|}{ Weight Normalized Value } & \multirow[b]{2}{*}{ Justification } \\
\hline & $\begin{array}{l}\text { Yamal } \\
\text { LNG }\end{array}$ & $\begin{array}{l}\text { Arctic } \\
\text { LNG-2 }\end{array}$ & $\begin{array}{c}\mathrm{Ob} \\
\text { LNG }\end{array}$ & $\begin{array}{l}\text { Yamal } \\
\text { LNG }\end{array}$ & $\begin{array}{l}\text { Arctic } \\
\text { LNG-2 }\end{array}$ & $\begin{array}{c}\text { Ob } \\
\text { LNG }\end{array}$ & $\begin{array}{l}\text { Yamal } \\
\text { LNG }\end{array}$ & $\begin{array}{l}\text { Arctic } \\
\text { LNG-2 }\end{array}$ & $\begin{array}{c}\mathrm{Ob} \\
\mathrm{LNG}\end{array}$ & \\
\hline $\begin{array}{l}\text { Creation of social infrastructure } \\
\text { in the region max, units }\end{array}$ & 3 & 0 & 0 & 1.0 & 0.0 & 0.0 & 3.3 & 0.0 & 0.0 & $\begin{array}{l}\text { Open source data. For the Yamal LNG project, it is a shift } \\
\text { settlement, a hospital, and a sports complex. For other projects } \\
\text { there is no information. }\end{array}$ \\
\hline $\begin{array}{l}\text { Reconstruction and } \\
\text { modernization of social } \\
\text { infrastructure in the region } \\
\text { max, units }\end{array}$ & 0 & 0 & 0 & 0 & 0 & 0 & 0 & 0 & 0 & Open source data (not available currently). \\
\hline $\begin{array}{l}\text { Gasification of Russian regions } \\
\text { max, units }\end{array}$ & 0 & 0 & 0 & 0 & 0 & 0 & 0 & 0 & 0 & Open source data (not available currently). \\
\hline $\begin{array}{l}\text { Greenhouse gas emissions, } \\
\text { min, million tons/year }\end{array}$ & 1 & 1 & 1 & 1.0 & 1.0 & 1.0 & 5.8 & 5.8 & 5.8 & $\begin{array}{l}\text { Based on the assumption of similar liquefaction technologies, } \\
\text { there is no reason to believe that greenhouse gas emissions will } \\
\text { be different. }\end{array}$ \\
\hline Gas flaring, min, thousand $\mathrm{m}^{3}$ & 1 & 1 & 1 & 1.0 & 1.0 & 1.0 & 5.3 & 5.3 & 5.3 & $\begin{array}{c}\text { Based on the assumption of liquefaction technologies similar in } \\
\text { technological characteristics, there is no reason to believe that the } \\
\text { volumes of gas flaring will be different. }\end{array}$ \\
\hline $\begin{array}{l}\text { Energy intensity of production, } \\
\text { min, LNG KW/ton }\end{array}$ & 1 & 1 & 1 & 1.0 & 1.0 & 1.0 & 11.1 & 11.1 & 11.1 & $\begin{array}{l}\text { Based on the assumption of liquefaction technologies similar in } \\
\text { technological characteristics, there is no reason to believe that the } \\
\text { energy intensity of production will be different. }\end{array}$ \\
\hline $\begin{array}{l}\text { LNG utilization volumes for } \\
\text { domestic vessel refueling, max, } \\
\text { thousand } \mathrm{m}^{3}\end{array}$ & 0 & 0 & 0 & 0 & 0 & 0 & 0 & 0 & 0 & Open source data (not available currently). \\
\hline $\begin{array}{l}\text { Volume of LNG used as gas } \\
\text { engine fuel for motor vehicles } \\
\text { and large machinery, max, } \\
\text { thousand } \mathrm{m}^{3}\end{array}$ & 1 & 1 & 1 & 1.0 & 1.0 & 1.0 & 3.7 & 3.7 & 3.7 & $\begin{array}{c}\text { Based on the information on the plans for the integrated use of } \\
\text { the Arctic LNG in Chukotka for electric generation and } \\
\text { transport, there is no reason to believe that the consumption } \\
\text { volumes will vary between projects. }\end{array}$ \\
\hline $\begin{array}{l}\text { LNG usage volumes for power } \\
\text { generation, max, thousand } \mathrm{m}^{3}\end{array}$ & 1 & 1 & 1 & 1.0 & 1.0 & 1.0 & 3.6 & 3.6 & 3.6 & $\begin{array}{c}\text { Based on the information on the plans for the integrated use of } \\
\text { the Arctic LNG in Chukotka for electric generation and } \\
\text { transport, there is no reason to believe that the consumption } \\
\text { volumes will vary between projects. }\end{array}$ \\
\hline & & Total & & & & & 75.5 & 52.6 & 36.9 & \\
\hline
\end{tabular}




\section{References}

1. Moe, A. The dynamics of arctic development. In Asia in the Arctic. Narratives, Perspectives and Policies; Sakhuja, V., Narula, K., Eds.; Springer: Singapore, 2016; pp. 3-15.

2. Glomsrod, S.; Mäenpää, I.; Lindholt, L.; McDonald, H.; Goldsmith, S. Arctic economies within the Arctic nations. In The Economy of the North; Glomsrod, S., Aslaksen, I., Eds.; Statistics Norway: Oslo, Norway, 2008; pp. 37-68.

3. Russian International Affairs Council. Arctic Region: Problems of International Cooperation. Volume 1; Ivanov, I.S., Ed.; Aspect Press: Moscow, Russia, 2013. (In Russian)

4. Center for Strategic Research. Arctic 18-24-35: The View of the Young. 2018. Available online: https://www.csr.ru/upload/ iblock/077 / 077bf5da0f50eeea20d3459409938f6a.pdf (accessed on 15 May 2020). (In Russian).

5. Nikulin, A.A. Mineral resources of Russia: Opportunities and prospects for development. Natl. Strategy Probl. 2017, 40, 163-187. (In Russian)

6. Dodin, D.A.; Kaminskiy, V.D.; Suprunenko, O.I.; Pavlenko, V.I. Nodal problems of ensuring the economic development of the Russian Arctic. Arct. Ecol. Econ. 2011, 4, 64-79. (In Russian)

7. Asheim, B.T.; Smith, H.L.; Oughton, C. Regional innovation systems: Theory, empirics and policy. Reg. Stud. 2011, 45, 875-891. [CrossRef]

8. Skufyina, T.P. Alternatives for the development of the Russian North. Reg. Econ. Theory Pract. 2011, 187, 2-9. (In Russian)

9. Krivovichev, S.V. Editorial for special issue "Arctic mineral resources: Science and technology". Minerals 2019, 9, 192. [CrossRef]

10. Gaynanov, D.A.; Kirillova, S.A.; Kuznetsova, Y.A. Russian Arctic in the context of sustainable development. Econ. Soc. Chang. Facts Trends Forecast 2013, 30, 79-88. (In Russian)

11. Smirnova, O.O.; Lipina, S.A.; Sokolov, M.S. Modern prospects and challenges for sustainable development of the Arctic zone of the Russian Federation. Trends Manag. 2017, 1, 1-15. (In Russian) [CrossRef]

12. Ermida, G. Strategic decisions of international oil companies: Arctic versus other regions. Energy Strategy Rev. 2014, 2, 265-272. [CrossRef]

13. Petrov, A.N.; BurnSilver, S.; Chapin, F.S., III; Fondahl, G.; Graybill, J.K.; Keil, K.; Nilsson, A.E.; Riedlsperger, R.; Schweitzer, P. Arctic Sustainability Research: Past, Present and Future; Taylor \& Francis Group Ltd.: Oxford, UK, 2017.

14. Carson, M.; Sommerkorn, M.; Behe, C.; Cornell, S.; Gamble, T.; Mustonen, T.; Peterson, G.; Vlasova, T.; Chapin, F.S., III. An Arctic resilience assessment. In Arctic Resilience Report; Carson, M., Peterson, G., Eds.; Arctic Council: Stockholm, Sweden, 2016; pp. 2-26.

15. Elhuni, M.R.; Ahmad, M.M. Key performance indicators for sustainable production evaluation in oil and gas sector. Procedia Manuf. 2017, 11, 718-724. [CrossRef]

16. Dale, B.; Veland, S.; Hansen, A. Petroleum as a challenge to arctic societies: Ontological security and the oil-driven 'push to the north'. Extr. Ind. Soc. 2019, 6, 367-377. [CrossRef]

17. Bogachev, V.F.; Veretennikov, N.P.; Sokolov, P.V. Regional interests of Russia in the concept of development of the Arctic. Vestnik MGTU 2015, 18, 373-376. (In Russian)

18. O'Garra, T. Economic value of ecosystem services, minerals and oil in a melting Arctic: A preliminary assessment. Ecosyst. Serv. 2017, 24, 180-186. [CrossRef]

19. Ilinova, A.; Chanysheva, A. Algorithm for assessing the prospects of offshore oil and gas projects in the Arctic. Energy Rep. 2020, 6, 504. [CrossRef]

20. Nilsson, A.E.; Larsen, J.N. Making regional sense of global sustainable development indicators for the Arctic. Sustainability 2020, 12, 1027. [CrossRef]

21. Litvinenko, V. The role of hydrocarbons in the global energy agenda: The focus on liquefied natural gas. Resources $2020,9,59$. [CrossRef]

22. Hönig, V.; Prochazka, P.; Obergruber, M.; Smutka, L.; Kučerová, V. Economic and technological analysis of commercial LNG production in the EU. Energies 2019, 12, 1565. [CrossRef]

23. Moe, A. A new Russian policy for the Northern sea route? State interests, key stakeholders and economic opportunities in changing times. Polar J. 2020. [CrossRef]

24. Mitrova, T.; Kapitonov, S.; Klimentiev, A. Volume 2. Russian Small and Medium-Sized LNG. Regional Series. Arctic. 2019. Available online: https://energy.skolkovo.ru/downloads/documents/SEneC/Research/SKOLKOVO_EneC_RU_Arc_Vol2.pdf (accessed on 15 May 2020).

25. Holden, E.; Linnerud, K.; Banister, D. Sustainable development: Our common future revisited. Glob. Environ. Chang. 2014, 26, 130-139. [CrossRef]

26. Report of the World Commission on Environment and Development: Our Common Future. 1987. Available online: https: / / sustainabledevelopment.un.org/content/documents/5987our-common-future.pdf (accessed on 25 November 2020).

27. Giddings, B.; Hopwood, B.; O'Brien, G. Environment, economy and society: Fitting them together into sustainable development. Sustain. Dev. 2002, 10, 187-196. [CrossRef]

28. Jeronen, E. Sustainability and sustainable development. In Encyclopedia of Corporate Social Responsibility; Idowu, S.O., Capaldi, N., Zu, L., Gupta, A.D., Eds.; Springer: Berlin, Germany, 2013. 
29. Purvis, B.; Mao, Y.; Robinson, D. Three pillars of sustainability: In search of conceptual origins. Sustain. Sci. 2019, 14, 681-695. [CrossRef]

30. Barbier, E.B. The concept of sustainable economic development. Environ. Conserv. 1987, 14, 101-110. [CrossRef]

31. Elkington, J. Cannibals with Forks: The Triple Bottom Line of 21st Century Business; Capstone Publishing: Oxford, UK, 1997.

32. Coşkun Arslan, M.; Kisacik, H. The corporate sustainability solution: Triple bottom line. J. Acc. Fin. 2017, 18-34.

33. Shchukina, L.V. Theoretical aspects of sustainable development of regional socio-economic systems. Pskov Reg. J. 2015, 21, 38-50. (In Russian)

34. UN. Transforming Our World: The 2030 Agenda for Sustainable Development. Available online: https:/ / sustainabledevelopment. un.org/post2015/transformingourworld (accessed on 11 November 2020).

35. Stepanova, N.; Gritsenko, D.; Gavrilyeva, T.; Belokur, A. Sustainable development in sparsely populated territories: Case of the Russian Arctic and far east. Sustainability 2020, 12, 2367. [CrossRef]

36. Azapagic, A. Developing a framework for sustainable development indicators for the mining and minerals industry. J. Clean. Prod. 2004, 12, 639-662. [CrossRef]

37. Ville, M.; Yang, L.; Tzong-Ru, L.; Jurgen, P. Extracting key factors for sustainable development of enterprises: Case study of SMEs in Taiwan. J. Clean. Prod. 2018, 209. [CrossRef]

38. Dvořáková, L.; Zborkova, J. Integration of sustainable development at enterprise level. Procedia Eng. 2014, 69, 686-695. [CrossRef]

39. Padash, A.; Ghatari, A. Toward an innovative green strategic formulation methodology: Empowerment of corporate social, health, safety and environment. J. Clean. Prod. 2020, 261, 121075. [CrossRef]

40. Filho, W.; Brandli, L. Engaging Stakeholders in Education for Sustainable Development at University Level; World Sustainability Series; Springer: Cham, Switzerland, 2016. [CrossRef]

41. Donaldson, T.; Preston, L. The stakeholder theory of the corporation: Concepts, evidence, and implications. Acad. Manag. Rev. 1995, 4, 65-91. [CrossRef]

42. Cherepovitsyn, A.E.; Ilinova, A.A.; Evseeva, O.O. Stakeholders management of carbon sequestration project in the state-businesssociety system. J. Min. Inst. 2019, 240, 731-742. [CrossRef]

43. Kates, R.W.; Clark, W.C.; Corell, R.; Hall, M.J.; Jaeger, C.C.; Lowe, I.; McCarthy, J.J.; Schellnhuber, H.J.; Bolin, B.; Dickson, N.M. Sustainability science. Science 2001, 292, 641-642. [CrossRef] [PubMed]

44. Searcy, C. The Role of Sustainable Development Indicators in Corporate Decision-Making; International Institute for Sustainable Development: Winnipeg, MB, Canada, 2009.

45. Wang, J.; Chi, H.-L.; Shou, W.; Chong, H.-Y.; Wang, X.A. Coordinated approach for supply-chain tracking in the liquefied Natural gas industry. Sustainability 2018, 10, 4822. [CrossRef]

46. Wu, J.; Wu, T. Sustainability indicators and indices: An overview. In Handbook of Sustainability Management; Madu, C.N., Kuei, C.-H., Eds.; World Scientific Publishing: Singapore, 2012; pp. 65-86. [CrossRef]

47. Meadows, D. Indicators and Information Systems for Sustainable Development. Available online: http://donellameadows.org/ wp-content/userfiles/IndicatorsInformation.pdf (accessed on 15 May 2020).

48. Poveda, C.A. Sustainability Assessment: A Rating System Framework for Best Practices; Emerald Publishing Limited: Bingley, UK, 2017.

49. Gunnarsdottir, I.; Davidsdottir, B.; Worrell, E.; Sigurgeirsdottir, S. Review of indicators for sustainable energy development. Renew. Sustain. Energy Rev. 2020, 133, 110294. [CrossRef]

50. Official Website of the Ministry of Economic Development of the Russian Federation. Available online: https:/ / economy.gov.ru/ (accessed on 22 April 2020). (In Russian)

51. Official Website of the Ministry of the Russian Federation for the Development of the Far East and the Arctic. Available online: https: / / eng.minvr.ru/ (accessed on 22 April 2020).

52. Velasquez, M.; Hester, P. An analysis of multi-criteria decision making methods. Int. J. Oper. Res. 2013, 10, 56-66.

53. Abdelli, A.; Mokdad, L.; Hammal, Y. Dealing with value constraints in decision making using MCDM methods. J. Comput. Sci. 2020, 44. [CrossRef]

54. Lamichhane, S.; Eğilmez, G.; Bhutta, M.K.; Gedik, R.; Erenay, B. Benchmarking OECD countries' sustainable development performance: A goal-specific principal component analysis approach. J. Clean. Prod. 2020, 125040. [CrossRef]

55. Tilla, I.; Blumberga, D. Qualitative indicator analysis of a sustainable remediation. Energy Procedia 2018, 147, 588-593. [CrossRef]

56. Zhou, L.; Tokos, H.; Krajnc, D.; Yang, Y. Sustainability performance evaluation in industry by composite sustainability index. Clean Technol. Environ. Policy 2012, 14. [CrossRef]

57. Litvinenko, V.S.; Sergeev, I.B. Innovations as a factor in the development of the natural resources sector. Stud. Russ. Econ. Dev. 2019, 30, 637-645. [CrossRef] 